University of Louisville

ThinkIR: The University of Louisville's Institutional Repository

$5-2021$

\title{
[Re]Fashioning a means: exploring and adapting Anna Cora Mowatt's fashion through a feminist lens.
}

Jordan Tudor Haggard

University of Louisville

Follow this and additional works at: https://ir.library.louisville.edu/etd

Part of the Acting Commons, and the Theatre History Commons

\section{Recommended Citation}

Haggard, Jordan Tudor, "[Re]Fashioning a means: exploring and adapting Anna Cora Mowatt's fashion through a feminist lens." (2021). Electronic Theses and Dissertations. Paper 3595.

https://doi.org/10.18297/etd/3595

This Master's Thesis is brought to you for free and open access by ThinkIR: The University of Louisville's Institutional Repository. It has been accepted for inclusion in Electronic Theses and Dissertations by an authorized administrator of ThinkIR: The University of Louisville's Institutional Repository. This title appears here courtesy of the author, who has retained all other copyrights. For more information, please contact thinkir@louisville.edu. 


\title{
[RE]FASHIONING A MEANS: EXPLORING AND ADAPTING ANNA CORA MOWATT'S FASHION THROUGH A FEMINIST LENS
}

\author{
By \\ Jordan Tudor Haggard \\ B.F.A., Roosevelt University, 2010

\begin{abstract}
A Thesis
Submitted to the Faculty of the College of Arts and Sciences at the University of Louisville In Partial Fulfillment of the Requirements for the Degree of
\end{abstract} \\ Master of Fine Arts in Theatre Arts \\ Department of Theatre Arts \\ University of Louisville \\ Louisville, Kentucky
}

May 2021 
Copyright 2021 by Jordan Tudor Haggard All Rights Reserved 

[RE]FASHIONING A MEANS: EXPLORING AND ADAPTING ANNA CORA MOWATT'S FASHION THROUGH A FEMINIST LENS

\author{
By \\ Jordan Tudor Haggard \\ B.F.A., Roosevelt University, 2010
}

A Thesis Approved on

April 07, 2021

by the following Thesis Committee:

Dr. Janna Segal

Professor Rachel Carter

Professor Frank Kelderman 


\section{DEDICATION}

For Beatrice and Charlie, who provide constant smiles and laughter. 


\section{ACKNOWLEDGEMENTS}

First, I would like to thank Dr. Janna Segal for her endless support and dedication to helping me write this thesis. I would not have this document without her encouragement and knowledge. Thank you to Dr. J. Ariadne Calvano for directing [Re]Fashion and pushing me to step out of my comfort zone. I thank Rachel Carter for guidance, Blair Potter for understanding, and Frank Kelderman for jumping onto my committee with so much enthusiasm. I am forever grateful to my $U$ of $L$ classmates for providing comfort and laughter. Thank you to my parents, Steve and Christy, and my sister, Casey, who supported my decision to go back to school and listened to me whine

about grading. Special thanks to Ian for repeatedly telling me that I was extraordinary and Sharon Combs, my grad school partner in crime who was always available at midnight to talk about school, Outlander, and snacks. And finally, thank you to my dog Dot, who literally sat next to me on the couch every step of the way. You all mean more to me than I could possibly say. 


\title{
ABSTRACT \\ [RE]FASHIONING A MEANS: EXPLORING AND ADAPTING ANNA CORA MOWATT'S FASHION THROUGH A FEMINIST LENS
}

\author{
Jordan Tudor Haggard
}

April 07, 2021

This MFA thesis explores gender representation in Anna Cora Mowatt's Fashion (1845) and the adaptation [Re]Fashion presented by the University of Louisville's Department of Theatre Arts in Spring 2021. Directed by Dr. J. Ariadne Calvano, University of Louisville faculty, staff, and students worked together to repurpose the script for a modern audience. Cast as the governess, Gertrude, I aimed to find truth in my character without ignoring the social prescriptions of mid-nineteenth-century America. Gertrude values purity and being good, virtues considered innately feminine by the period's cultural feminists. I argue that Fashion is a cultural feminist work and Gertrude is a cultural feminist character. I detail how historical research, image work, Stella Adler acting techniques, and Jo Estill's Voice Training helped me build a more confident, legibly restrictive Gertrude for the adaptation. I have offered these techniques so other actors can consider the gender politics of period pieces and similarly realize their character's resistance. 
TABLE OF CONTENTS

$\begin{array}{lc} & \text { PAGE } \\ \text { DEDICATION } & \text { iii } \\ \text { ACKNOWLEDGEMENTS } & \text { iv } \\ \text { ABSTRACT } & \mathrm{v} \\ \text { LIST OF FIGURES } & \text { vii } \\ \text { INTRODUCTION: HESITATION AND REALIZATION } & 1 \\ \text { CHAPTER ONE: BIOGRAPHY OF AN ACTRESS } & 11 \\ \text { CHAPTER TWO: A LOVE OF INDEPENDENCE } & 26 \\ \text { CHAPTER THREE: REDESIGNING WOMEN } & 41 \\ \text { CHAPTER FOUR: COMPOSING GERTRUDE } & 54 \\ \text { CONCLUSION: [RE]FASHION IS THE LATEST FASHION } & 70 \\ \text { REFERENCES } & 74 \\ \text { CURRICULUM VITAE } & 77\end{array}$




\section{LIST OF FIGURES}

FIGURE $\quad$ PAGE

1. A nineteenth-century cage crinoline 31

2. A nineteenth-century overbust corset 31

3. Women in the Garden by Claude Monet 34

4. Jean-Pierre Duvelleroy’s Fan Language 39

5. The Irritating Gentleman by Berthold Woltze 57

6. The Reluctant Bride by Auguste Toulmouche 60 


\section{INTRODUCTION:}

\section{HESITATION AND REALIZATION}

"Creativity is a wild mind and a disciplined eye." - Dorothy Parker

My journey to my thesis suddenly took a detour in the middle of March 2020. I

went from planning to perform the title role in Henrik Ibsen's Hedda Gabler for my 2021

MFA thesis to wondering if I would ever step foot on a stage at the University of

Louisville again. COVID-19 had thrown the world for a loop, and traditional theatres all

over the country went dark. It became clear to director Dr. J. Ariadne Calvano that Hedda

Gabler would not lend itself to a virtual world. Dr. Calvano contacted me to let me know

that she would be changing the production to a then unwritten adaptation of Anna Cora

Mowatt's American comedy of manners Fashion (1845) and that I should consider the character of Gertrude for my MFA thesis role.

I waited a few days to read through the not-yet-adapted script and when I finally did, I instantly frowned upon the arrival of Gertrude. Mowatt's Fashion introduces her entirely in white, twirling amongst the flowers (18). This character was something I had never played and had constantly avoided: she is an ingénue. She wears a symbol of virginity and speaks about truth and her honor. Gertrude's last line in Mowatt's play is "Virtue her own reward!" (79), and every time I attempted to say it when reading, I physically flinched. I was not sure I would be able to cast aside my judgment and end the play with that phrase. I thought instantly that directors would not normally cast me as this character. I have spent my time as a professional actor playing the dumb or sarcastic best 
friend. Because of this, I panicked and suggested to Dr. Calvano that the role of the French maid Millinette would be a better fit. After all, my curvy body type lent to the sexualized stereotype of a French maid, and Millinette was funny and charming. Dr. Calvano told me to think about it and that the decision did not need to be made right away.

I reached out to my thesis advisor, Dr. Janna Segal, to tell her I was deciding between the two characters and asked if she had any thoughts. When she asked me why I was hesitant to commit to Gertrude, I admitted that I thought she was boring. Dr. Segal encouraged me to consider that this female character that I found boring would present a challenge. I spent my time at the University of Louisville playing roles fit for character actors and leading ladies. An ingénue would provide diversity on my resume and allow me to perform a different character type. Since this was an adaptation, Mowatt's version of the play was not the final product, and Dr. Segal reminded me that things were going to change. Gertrude would be shaped by me during the rehearsal process. I agreed to reconsider my initial skepticism and went back to re-read the script, resigning myself to the thought that I would probably end up playing the boring girl in white.

As my summer break began, I agreed to take on the challenging role, but I decided that I would not be happy about it. I started gathering sources and reading about Anna Cora Mowatt, whom I labeled a villain. How dare she write a play where men save the day and the women fall into two categories: coquettes or virgins. I was upset by the character of Zeke aka Adolph (renamed Beaumont in our adaptation), the wacky butler meant to be played in blackface. As a feminist, bleeding heart liberal, I do not find stories where men run everything and "save" the poor women interesting. I read 
Gertrude's grandfather, Adam Trueman, and saw every old man that had ever told me to smile looking up at me from the page. Near the end of the play when Gertrude asks Adam to help the Tiffany family he snaps back, "Enough--I did not need your voice, child" (Mowatt, Fashion 77) and Gertrude does not speak again for several pages. Gertrude is finally given a father figure and one of his first acts after that acknowledgment is to tell her to be quiet. Gertrude obeys and stays silent for the next few pages. My feathers were ruffled, but I decided to keep researching. I read Alison Piepmier's discussion of racism in Mowatt's plays which caused frustration, and I refused to enjoy the play.

Looking back, I realize I was pushing against the change in my world due to COVID-19. I have been diagnosed with Obsessive Compulsive Disorder and a global pandemic has been difficult for my mental health and reasoning. Add to that the change from Hedda Gabler to Fashion and from live theatre to Zoom theatre, and I was suddenly tense. I felt I had no control over my thesis anymore, and I was taking it out on a dead woman and the character I was playing. Without realizing it, I was still mourning playing Hedda Gabler. Because my brain can become hyper-focused on certain things, I looked at Anna Cora Mowatt and Gertrude as my enemies. I insisted that I had nothing in common with Gertrude, that Mowatt was a terrible writer, and that this play was irrelevant. This was exacerbated by the fact that I was in lockdown with my parents while trying to get over my complete fear of a virus that I did not know much about. The Spring semester of classes had ended by this time, giving me long periods to obsess over the sexism in the play. I know now that the play's gender representations are a product of a society where men dominated politics, economics, and family life. However, in June, all I could think about was how Mowatt wrote men better than women and maybe I should ask the 
director if I could instead play one of the male characters like Count Jolimaitre or Mr. Snobson.

This frustration appeared in the first draft of my annotated bibliography and thesis abstract. I was judgmental in my annotations and suggested that Gertrude was a difficult character for a feminist to play. Dr. Segal pointed out my tone and asked if I would have felt the same way about Henrik Ibsen if I were still working on Hedda Gabler. I thought that my critique of Fashion was going to help me discover what I would write about for my thesis, but all I was doing was making it harder for me to enjoy my thesis work. I wrote the following in my journal that evening:

A research 'problem' does not require looking at the show or characters in a negative light. Anna Cora Mowatt was a product of her time and putting her in the spotlight and dissecting her every move is just internal misogyny. This woman forged a path for herself and followed her dreams in a time when women were considered less than. I need to focus my question more on how an actor can play a role from the 19th century when she considers herself a modern feminist. I think I see more of myself in Gertrude than I want to. 'Ugh, she's boring. Nobody cares about virtue.' Well, Jordan, everyone cared about it in the 1860s (1), the period in which the adaptation of the 1845 play would be set.

I realized that I was hiding behind my feminism when I could be using it. I had put up a shield of pink knit anti-Trump hats and ignored the fact that social mores did not allow American women in the 1860s, the period in which our adaptation took place, to march in the street or pursue any job they wanted without severe punishment. I had to 
find a way to be true to the period and true to myself. After all, Gertrude spends the play trying to be true to herself. I decided to explore how, as a self-proclaimed "Nasty Woman," I could successfully develop a female character from 1860 without criticizing her or rewriting social rules.

This process has led to me think about what my idea of a feminist character is. My historical research has helped me realize that there is not one definition for the word "feminism," especially when it comes to working on period pieces. As a creative human, can I adapt a character from 1860 for a contemporary audience? What are ways artists can bring problematic characters and writing into the 21 st century while still telling important stories from American history? By examining the historical context of the play as well as unpacking it with other actors, I think it is possible to present the story of Fashion in a way that allows the audience to comfortably connect with the characters while acknowledging problematic aspects of the story.

\section{Refocusing}

After I came to this realization about Mowatt's writing, I started to worry about my own. I looked at the first draft of my abstract and bibliography and decided that I had already failed my thesis as well as feminism 101. Mowatt was working under extreme patriarchal conditions, and her ability to become a successful playwright and actress at the time is astonishing. While the mid-nineteenth-century was full of popular female writers that had the chance to write for women's magazines and publish novels, the theatre world was severely lacking. Theatre was considered a lower-class profession for women, so professional female playwrights at the time were almost unheard of. When Mowatt suggested starting a career in the theatre, she was warned that it would ruin her 
reputation. Writing Fashion led to Mowatt being the the first American female playwright to have a production professionally produced in New York City. I refocused and started to think about the ways that I could find feminism in the play and in Gertrude. My tools for doing this include historical research of women's lives in the period including the constructs placed on them, what feminism was at the time, as well as using acting techniques taught by women. Mowatt's play can be considered a feminist piece if one looks at the type of feminism she was practicing. As defined by Jill Dolan in The Feminist Spectator as Critic, Fashion and its female characters represent the now critiqued cultural feminism which "is founded on a reification of sexual difference that valorizes female biology, in which gender is an immutable, determining, and desirable category" (Dolan 6). Because Gertrude is looking for independence as a woman, she does not want what the men have or consider the genders equal, and she uses her femininity to achieve her goals. For this thesis, I will be applying Dolan's definition of this branch of feminism to identify how the play might be understood as feminist.

In chapter one, I will discuss Anna Cora Mowatt and her inspiration for writing Fashion, as well as the difficulties a female writer and actress faced in the period. By presenting the limitations placed on women by the patriarchy, I will confirm that she had to write her play to fit into the patriarchal structure of the period. Mowatt also wrote characters that allowed female actresses (including herself) to be on stage and work without being labeled whores or bad women. By presenting extremely feminine characters that followed social rules, Fashion allowed actresses to grace the stage respectably. These elements support my idea that Fashion can be read through a cultural feminist lens. 
Chapter two will dive deeper into the rules of the period, how they are placed on the character of Gertrude, as well as the subtle ways she rebels against these rules. I will discuss Gertrude's love of independence, and the accomplishments that allow her to be a working woman. Using historical texts, I will outline what Gertrude's job entailed. This research led to a discovery that women working in wealthy homes had very high expectations placed on them. I also explain different ways that Gertrude was pushing against the restraints provided by the Tiffany family, Count Jolimaitre, Adam, and her clothing. Gertrude does not follow the fashion that Mrs. Tiffany does. Her dresses are plain and she does not seem to have an issue digging in the dirt. When male characters like Count Jolimaitre invade her space and talk over her, she uses her body language to show discomfort instead of her words. In their first scene together in Mowatt's text, Count Jolimaitre refers to her as "little Gertrude" and "ma belle petit" (27), then interrupts her to tell her that he finds her attractive. He plans to bring her along as a mistress when he marries Seraphina (27). He insinuates that she should be thrilled that he is making an advance on her because he is superior to her and she is nothing but an orphan with no friends (27). In the first read-through, I noticed myself showing Gertrude's annoyance on her face whenever the Count was being rude to her. While there may be space for a few moments of her face failing her, social constructs would require her to be polite to a man of such a high rank. In Dr. Calvano's Period Movement class, we started to explore Jean-Pierre Duvelleroy's fan language, and I was immediately drawn to it as a tool to show Gertrude's frustration or nerves. The fan language provided a safe way for women to express their feelings and I knew Gertrude would have a fan in several of her scenes. I connected this to the fact that she was a piano player and decided 
that Gertrude expels energy and shows emotion with her hands. Connecting back to Dolan's definition, Gertrude uses the tools given to her as a woman to subtly express her feelings while following the rules of the house and period.

Chapter three will focus on the adaptation process as well as working on a theatre piece on Zoom. The revisions and additions to the script allowed me to present a stronger, more confident Gertrude than the one in Mowatt's script. Originally, I hesitated to change Gertrude too much. I found it important to keep to the period. While we were cutting lines and switching who said things around, I still wanted her to be the smart young woman that values her virtue. Lines were added and rewritten for her, especially near the end of the play when she is feeling brave enough to speak her mind. As she writes home to the women who raised her, Adam walks into the room to tell her goodbye (Mowatt, 61). He discovers that she was attempting to uncover Count Jolimaitre as an imposter and announces that she is a "true" woman (62). Originally the scene is run by Adam Trueman and Gertrude quietly accepts his overbearing attitude. However, in [Re]Fashion, Gertrude snaps back at his prying questions and sticks up for herself. This scene in [Re]Fashion sets a new tone for Gertrude for the remainder of the play, she gets her confidence back after being exposed in a closet with Count Jolimaitre and calls him out in front of the entire household.

By being a part of this rewriting process, I was allowed to bring my feminist lens to Gertrude's scenes. I suggested minor line changes and discussed my feelings about how Gertrude's journey should go with director Dr. Calvano, dramaturg Dr. Segal, and the assistant director Blair Potter. When our first six drafts had Gertrude's story ending in marriage, I suggested that it could be left open to interpretation instead. If I was going to 
play a woman that loves independence, I found it important she keep that independence in the end instead of bending to society's expectations of marriage.

Chapter four will cover my acting process and the movement and voice work I did to help create a more confident Gertrude. I gathered images of women in the period and made a Pinterest board to hold them all. I knew I wanted to discuss how Gertrude moved in the many layers she would have worn, but I also wanted to figure out a way to show rebellion in that movement, even if it was so tiny that only I knew it was there. In a world where women could not show too much emotion (unless they wanted to be labeled hysterical), I knew small gestures would save Gertrude from exploding in frustration. In a slightly selfish move, they would also help me from exploding in frustration. I have yet to master how to play someone that is considered still and calm, stillness on stage immediately throws me into my head.

Because of the feminist focus of my thesis, I gravitated to female acting teachers and started reading Stella Adler and the Jo Estill method. Adler is important to me as an actress because she offers a feminist lens on "method" acting. Method acting involves using emotional recall to help an actor achieve their "tasks" and goals as a character. Stella Adler studied the method technique under Lee Strasberg, the leading method teacher in America at the time. Using emotional recall and past experiences can make rehearsals difficult. Directors and teachers may ask an actor to focus on certain trauma or tragedy in their lives to make a performance feel "real." Feeling abused by this approach, Adler created a different, safer technique. Adler emphasizes using imagination to build a character's world and this can prevent the emotional abuse that occurred in method classrooms. Estill offers options on voice work that do not describe women's voices as 
"whiny" or "shrieking," two words that have often been used by men to describe my voice. I never knew that being loud and having a higher pitched voice made one a banshee, but some men in the theatre certainly seem to think so. By using these techniques, I felt the freedom to play with Gertrude away from a male gaze.

It can be challenging to act in a period piece as a modern feminist. Upon my first read-through, I became obsessed with the antiquated practices presented in the play. Through the adaptation process, I have modernized Gertrude and helped bring Fashion into the 21 st century. It is vital to research the period and think about why a woman may be making certain choices. My wish for this thesis is that it inspires other actors to dig deeper into the "why" of social constructs presented in period pieces. I have managed to find agency and truth in Gertrude's movement and character despite my initial judgments and negative thoughts. I also hope I can motivate other female actors to think outside of the box when working on ingénue roles and upset the patriarchy while smiling and smelling the flowers. 


\section{CHAPTER ONE:}

\section{BIOGRAPHY OF AN ACTRESS}

"It has been the men who have done the law making and the money making and most of the mischief making. So, if the world isn't quite what you had in mind, you have only yourselves to thank." - Julia Sugarbaker, Designing Women

This chapter will present Anna Cora Mowatt's life and inspirations for writing Fashion and the struggles female writers and actresses faced in the period due to limitations put on women working outside of the home. Mowatt challenged the period's patriarchal standards by being a successful playwright and actress and writing a play that allowed women to work and perform "respectable" parts on stage. During this period, women were writing for magazines and publishing novels, but the theatre world was still dominated by men. Mowatt would risk societal ruin to become the first professional female playwright in New York City. As will be shown, Mowatt had to in part cater to the demands of the male-dominated theatre industry. to get her work produced. Fashion ends with Adam Trueman as the hero and male characters deciding the fates of the women. Mowatt was performing a feminist act by publicly working as an actress and writer, supporting her family, and writing female characters that fit into respectable female conventions of the time. Women on stage could play matriarchs or innocent ingénues without being labeled jezebels (Chinoy 25). These roles are amplified in Fashion, especially in Mrs. Tiffany and Seraphina. These exaggerated stereotypes allow the reader to look at Fashion through a cultural feminist lens. 
As defined by my Introduction, "cultural feminism is founded on a reification of sexual difference that valorizes female biology, in which gender is an immutable, determining, and desirable category" (Dolan 6). Using this definition and that from Donovan's Feminist Theory, I will examine the play as a feminist work which lifts up feminine virtues, while Gertrude's role as a cultural feminist character will be presented in Chapter 2. Throughout the thesis, I will point out moments in the play that lend themselves to cultural feminism and include desirable merits such as honesty, purity, and having a maternal nature. I will also give Mowatt's history, including moments in her life where she defied society's expectations and helped women work outside of the home. Mowatt's defiance of a woman's role in the theatre world influenced her female characters and critiqued female gender constructions of the period.

\section{Herstory}

Even as a child, Anna Cora Mowatt was drawn to a life of performance and writing female-centered plays that challenged the status quo. Mowatt was born Anna Cora Ogden, the youngest daughter of Samuel and Eliza Ogden, in 1819. She lived in Bordeaux, France with her family until, at age seven, they moved to America. Along with her nine siblings, she spent her time as a child performing plays in the backyard (Barnes 5). Mowatt took it upon herself to write plays for her siblings to perform. According to Anna Cora Mowatt: Forgotten Dramatist and Actress, Mowatt wrote plays for her family "without the usual male protagonist" (86). Mowatt was later sent to a boarding school in New Rochelle with her sisters, where she was "completely miserable" (Barnes 12).

As a young woman, Mowatt began to break the gender rules society had set. At the age of fourteen, she met her first husband, Mr. James Mowatt, a lawyer fourteen years 
her senior. They bonded over their love of Shakespeare and eloped a year later, quickly moving to New York without the permission of Anna's parents (Barnes 28). While this was not Mowatt's first act of rebellion at the time, it was the most extreme decision she had made for herself. By secretly marrying James Mowatt and moving to New York, Mowatt became geographically closer to the professional theatre world and defiant of her father, who had asked her to wait two more years to get married (Mowatt, Autobiography 57). For a young woman that had just been introduced to society, defying her father's wishes was a feminist act. At this point in history, men led households and governed the future of their daughters. The act of choosing her husband and marrying in secret was Mowatt's first big action of defiance and independence. In his biography of Mowatt, Eric Wollencott Barnes claims that she spent her life trying to "break the mold" (12) and insists that she played an equal part in concealing their marriage from her family. After their marriage, Mowatt was encouraged by her husband to continue her writing and love of theatre (Barnes 35).

Mowatt would eventually subvert expectations to become the main source of income for the household. Ten years into their marriage, the Mowatts' very comfortable life was threatened when James Mowatt became ill and unable to do his job. He had also lost a large sum of money by purchasing bad stocks, leading to the family's financial struggle (Barnes 63). Mowatt started her theatrical career doing poetry readings and was warned by her sister that performing would change her social status for the worse (Autobiography 142). Nevertheless, she continued to perform these readings until a respiratory illness made it impossible for her to project in large theatres (Barnes 88). Mowatt managed to prove her sister wrong, as her readings made her a popular name in 
the theatre. She challenged her family and society's expectations by stepping onto a stage and becoming one of the first upper-class female performers in New York (Shapiro 86).

Not one to give up when presented with a challenge, Mowatt continued her theatrical career despite her illness. Mowatt writes in her autobiography that after recovering, a friend of hers suggested she write a play, which became Fashion (202). Mowatt would become the first American woman to have a play professionally produced at the Park Theatre in New York. In spite of negative reviews from Edgar Allen Poe, Fashion was a successful comedy of manners (Mowatt, Autobiography 213). Mowatt's resolve to continue her work in the theatre despite potential consequences is admirable. Mowatt persevered in the male-driven world of playwriting, which is a testament to her resolve and determination to pave her way and succeed outside of the home.

\section{Women Beget Women}

Anna Cora Mowatt was defying mid-nineteenth-century American societal standards by being a public author and actress. By becoming a playwright and actress, she was vulnerable to scrutiny by the public eye. At the time, a life in the theatre was a double-edged sword for women. While it provided a way for women to earn money, acting could have a drastic impact on their reputation. In "Art Versus Business: The Role of Women in American Theatre," Helen Krich Chinoy explains that in the midnineteenth-century, the United States was "a country where theatre was thought of as Satan's haunt and actresses often equated with harlots" (25). There was always a possibility that Mowatt's reputation could be ruined by becoming a part of the theatre. Still, as we learned earlier, Mowatt was never one to shy away from doing something in defiance of social norms. 
Actresses at the time had few choices regarding what they could do on stage. They could use their sexuality to make a living while being shunned by society or fit themselves into gender-based character conventions (Chinoy 25). These included the ingénue, the wife, or the fallen woman (Chinoy 25). Mowatt used these female character types in her writing to provide a safe space for actresses. While on the surface it may seem that Mowatt was judging the women in Fashion, she was actually creating work for women (and herself) so they could gain independence in what she defended as a respectable profession. In her autobiography, Mowatt names the actresses that appeared in Fashion while it was running and compliments their hard work and talent (208-09). A running joke in Mowatt's play is Mrs. Tiffany's pronunciation of French. She is studying the language to "accommodate herself to everything foreign" (5) but pronounces "je ne sais quoi" as "jenny-says-quoi" (4) and "bon soir" as "bon swear" (45). While Mowatt is making fun of Mrs. Tiffany being a francophile with no understanding of the language, she still presents a matriarch concerned for her child and family's well-being. The humor in Mrs. Tiffany's character is innocent, making the role an acceptable female character type.

The story of the Tiffany family provides a look into how Mowatt believed women should behave in society. Fashion takes place in New York City in the home of Mr. and Mrs. Anthony Tiffany as Mrs. Tiffany prepares for Seraphina's suitors to arrive. One by one, the audience meets various men vying for Seraphina's hand, including Mr. Tiffany's clerk Mr. Snobson and the renowned Count Jolimaitre. Throughout the play, Mrs. Tiffany does her best to set up an engagement for Seraphina with the Count, which includes spending money on a new carriage and throwing a large ball despite financial 
troubles. The farmer and old friend of Mr. Tiffany's, Adam Trueman, arrives and attempts to set things right in the home, but he discovers that the Tiffany family is too obsessed with fashion to listen. In the end, Adam Trueman takes over and resolves the play by suggesting the Tiffany women live their life as the governess Gertrude did in the country. The play concludes with the Count walking in to be exposed as a fraud to the entire household and the Tiffany family sent away to the country to escape fashionable society. Adam Trueman tells Mr. Tiffany that his wife and daughter must "learn economy, true independence, and home virtues, instead of foreign follies" (77). These are the elements that make Gertrude an ideal woman. She embraces these "home virtues" and Trueman lifts them as traits perfect for teaching women.

Reading the play with a cultural feminist lens shows that the female characters of Fashion embrace their femininity and do not question their household roles. In Feminist Theory: The Intellectual Traditions of American Feminism, Josephine Donovan explains the concept as follows, "Instead of emphasizing the similarities between men and women, they often stress the differences, ultimately affirming that feminine qualities may be a source of personal strength and pride" (31). For instance, this pride is shown when Mrs. Tiffany talks of the expectations put on a house of their standing. She argues with Mr. Tiffany about it at the beginning of Act III as he demands she cut her spending, "There is a certain display which every woman of fashion is forced to make" (Mowatt, Fashion 35). Her spending and obsession with being in fashion are not frivolous; she knows that Seraphina's future depends on a wealthy suitor. It is part of her role as a mother to display herself and her daughter in an attractive way to eligible bachelors. Being concerned with fashion was something middle and high-class women were expected to 
do. By having pride in her clothing and household, she shows the world that she takes her role as matriarch seriously. The play also shows how ridiculous the expectations were for women running a household during the period. Mrs. Tiffany spends the play worrying about the reputation of her home. If her daughter does not marry well, the family name will be ruined as the Tiffany's have no other child. The plot shows just how dangerous expectations can be. When it is revealed that Seraphina has run off with Count Jolimaitre, Mr. and Mrs. Tiffany immediately start to worry:

MR. TIFFANY. Then I am ruined! [Stands with his face buried in his hands.]

MRS. TIFFANY: Oh, what a ridiculous girl! And she might have had such a splendid wedding! What could have possessed her?

MR. TIFFANY: The devil himself possessed her, for she has ruined me past all redemption (68).

Like Mowatt, Seraphina has picked her own husband and left to marry in secret. However, her parents know that this will lead to their ruin. Seraphina could have married Count Jolimaitre publicly and saved everyone from this embarrassment but the simple act of a young woman making her own choice hurts the family.

Since Mowatt was writing a satire, she could exaggerate these feminine gender roles to poke fun at them. In American Feminist Playwrights, Sally Burke states that Mowatt's feminist ideas require a closer look at the text: "Perhaps Mowatt's fall from wealth and privilege awakened the feminist consciousness with which she examines stereotypical ideas as women running men into debt, being horrified of aging, and overcome by jealousy" (22). Burke affirms that Mowatt's play is a feminist work and her 
comedy encourages the audience to consider how absurd it is that women are written off as being jealous creatures that must stay youthful. Mowatt uses humor to challenge the nineteenth-century American audience's perception of women as jealous and obsessed with their appearance. When Mrs. Tiffany exclaims, "A woman of fashion never grows old! Age is always out of fashion" (8), the audience may have laughed, but they might also have considered why women were so terrified of aging. To be in fashion means to be desirable, and older women were not regarded as alluring by society. The older Prudence is disregarded as a joke when she attempts to flirt with Adam Trueman. Equally important is Mowatt's consideration of jealousy between two women. In Act III, when Gertrude catches the Count in the room of the maid Millinette, he wags his eyebrows about women being hard to handle, "Oh, I never could manage two women at once,-jealousy makes the dear creatures so spiteful" (38). The audience is meant to laugh at the Count's assumption that they are motivated by "jealousy." Rather than being spiteful to each other, they are questioning his motives.

Meanwhile, Gertrude uses her femininity to trick Count Jolimaitre in Act III scene ii. When he threatens to tell Mrs. Tiffany that she is being rude to him, her demeanor quickly changes, and she becomes the demure, coy woman he wants her to be. This scene allowed me to play with the over-exaggeration of Gertrude's feminine traits. When she says, "His own weapons alone can foil this villain" (48), she means exaggerating who she is and playing a part. In this scene, she chooses to use her feminine wiles to fool him into thinking she does not understand the situation. Displaying herself as a meek woman, too bothered to continue with conflict, works in her favor as the Count believes her and 
agrees not to tell Mrs. Tiffany that she was rude to him. When she yields to him, the Count basks in his irresistible charms:

\section{GERTRUDE. Sir--Sir--Count! [At the last word the COUNT turns]}

Perhaps, Sir, the least said about this matter the better!

COUNT JOLIMAITRE: [Delightedly] The least said? [Aside] We won't say anything at all. She's coming round--couldn't resist me! Charming Gertrude-- (48).

Gertrude's sudden reverence of the Count's title and quick demeanor change prove that this moment is performance to get her way. As soon as Gertrude puts on her mask in this scene, Count Jolimaitre responds by calling her "charming Gertrude" (48) and treats her with respect.

Gertrude offers a different exaggerated version of femininity in the period, though this took me weeks of reading the play to figure out. Gertrude is a straight character, meaning she maintains composure amongst the eccentricities in the play. I referred to her as boring in my Introduction because I felt that she was the least funny of the characters. Still, the message behind Gertrude is deeper, especially for the time. She exclaims her "love of independence" in her first scene (26) and takes it upon herself to independently oust Count Jolimaitre. Josephine Donovan writes that part of cultural feminism in the nineteenth-century was that "women must develop self reliance" (33). Gertrude is self reliant through most of the play because she does not have anyone else she can trust with the information she has gathered. At the end of Act III, Gertrude states that she is capable of fixing the situation in the house: "I must devise some plan for opening their eyes. Truly, if I cannot invent one, I shall be the first woman who was ever at a loss for a 
stratagem--especially to punish a villain or to shield a friend" (49). She knows that women can take matters into their own hands and fix the problems men have caused.

However, her independence is fragile and can easily be taken away from her the moment Mrs. Tiffany accuses her of impropriety. It took one lie from Count Jolimaitre to ruin her professional life and put her on the street. Gertrude's only option is to write a letter to the women who raised her, informing them that she will be returning to the country. The play suggests a woman's independence at the time is a farce as well. When she claims that she has a right to be heard so she can explain being caught with the Count, Adam Trueman talks over her: "Right? How dare you have the face, girl, to talk of rights? You had more rights than you thought for, but you have forfeited them all! All right to love, respect, protection, and to not a little else that you don't dream of. Go, go!" (60). Though Adam has spent the entire play calling the Count a liar, he casts Gertrude out at the slightest bit of doubt. Her position is fragile. Gertrude may love the idea of working and living on her own, but she does not own anything. Even when she is saved in the end by Adam Trueman announcing he is her grandfather and Millinette's confession that the Count is an imposter, Adam treats her as a possession. He even disposes of her when he states to Colonel Howard that "Gertrude is yours" (70). Her independence is fleeting and requires the men in her life to allow it. Gertrude accepts this because it is her place as a woman in the period. She fulfills Dolan's description of a cultural feminist character by obeying the men in her life and accepting the marriage presented to her. By agreeing to the marriage, Gertrude's place as a woman in the family structure is established. She listens to the father figure to be presented to another man. She embraces her role as granddaughter and fiancé. 


\section{The Play's the Thing}

In the play, Gertrude represents the ideal young woman that values independence and virtue. Gertrude, an orphan and the governess to Seraphina Tiffany, begins the play tending to her duties around the house and in the garden. One of Seraphina's suitors, Count Jolimaitre, finds her in the garden and suggests that they begin an affair. Insulted, Gertrude rebukes his advances and is rescued by Adam Trueman. Throughout the play, Gertrude seeks to discover what the Count's motives are in the Tiffany household. As the Count has already expressed his interest to have her as a mistress, Gertrude knows this will lead to a life of constant threat of sexual assault or require her to quit her job. She quickly discovers that he is an imposter and sets out to prove this to the family. Unfortunately, her plan to oust the Count goes awry and she is found in a dark room with him alone. He suggests to Mrs. Tiffany that Gertrude had invited him there for inappropriate reasons. Mrs. Tiffany promptly fires Gertrude, calling her a ruined woman and insisting she pack. Gertrude accepts her fate at this moment, as she knows a woman's word against the Count's is meaningless.

A cultural feminist reading of this section supports Gertrude's choice to leave the house without a fight, which could hurt her reputation even more. After she is left alone in Millinette's room, she realizes the consequences of her actions, "This is too much! How heavy a penalty has my imprudence cost me!-- his esteem, and that of one dearer-my home--my--[burst of lively music from the ballroom] They are dancing, and I--I should be weeping, if pride had not sealed up my tears" (60). Because Gertrude was blinded by "pride," a trait not considered innately feminine in cultural feminism, she has been reprimanded and lost her "home." Gertrude writes a letter to the women who raised 
her, preparing them for her return as Adam Trueman enters to scold her for her behavior. After reading her letter, Adam realizes that Gertrude was telling the truth and that the Count is an imposter. They approach Mr. and Mrs. Tiffany, and Adam confesses that he is Gertrude's grandfather who gave her up to be raised to be independent, without money to corrupt her. He gives his consent to the engagement of Colonel Howard and Gertrude and they live happily ever after.

Adam Trueman is meant to be the hero of Fashion, as he drives the resolution and is the only "true" man in the play; however, Gertrude shapes the action throughout. Mowatt admitted that he is the only character based on an actual acquaintance: "The only character in the play which was sketched from life was that of the blunt, warmhearted old farmer" (Autobiography 203). A director once told me that every actor looks at their character as the protagonist in a play, as the story they build for themselves revolves around that character. It may therefore be a bit cliché to say that Gertrude is the actual hero. Yet, she gathers all of the information to expose Count Jolimaitre and is the "wit" of the play. Gertrude orchestrates a plan to have the Count caught in a lie. This plan involves a clever, detailed distraction for Millinette and Mrs. Tiffany, in which Gertrude researches Parisian fashions and sets up a basket of bouquets for every woman at the ball. Her cleverness extends to her lines as well. She has more wordplay than other characters. For instance, when talking to the Count in the garden, Gertrude uses his words against him:

COUNT JOLIMAITRE. Ma belle petite, were you gathering roses for me? GERTRUDE: The roses here, Sir, are carefully guarded with thorns--if you have the right to gather, pluck for yourself! 
COUNT JOLIMAITRE: Sharp as ever, little Gertrude! But now that we are alone throw off this frigidity, and be at your ease.

GERTRUDE: Permit me to be alone, Sir, that I may be at my ease (27). In the first line, Gertrude is not merely talking about the flowers around her. She is also guarded at this moment because she cannot be caught alone with the Count. The Count responds with "sharp as ever," which indicates this is not the first time he has made an advance and been rebuffed by Gertrude. As the Count suggests she be at her "ease," Gertrude flips the phrase and informs him that she can only do that by being "alone." His presence prevents her from being relaxed, as he is a man of higher status. Due to her position in the household, she is required to listen to him. She politely requests his departure so she can continue her work in peace. This brief encounter shows how quickwitted Gertrude can be, even in a stressful situation.

Although Gertrude plays a prominent role, it was not possible at the time for Mowatt to present a female hero. In American Feminist Playwrights: A Critical History, Sally Burke pronounces that Gertrude is the "would-be-hero" of the play: "Because Mowatt is, at base, pragmatic in her picture of society, Gertrude, the would-be hero, must yield to the patriarchy at the drama's end" (25). At the conclusion, Adam Trueman steps forward to "fix" everything by sending the Tiffanys to the country so Mrs. Tiffany and Seraphina can learn to be "true" like Gertrude. When Gertrude speaks up in the final scene, Trueman tells her to be quiet: "I did not need your voice, child" (75). After being told by the play's "true" man that there was no "need" for her "voice," she spends the next three pages obediently quiet. Male audiences at the time may not have responded well to a young woman as the protagonist. Had Mowatt not ended her play with a man as 
the problem solver, it may have gone unproduced. Thus, Adam Trueman takes over at the end with a series of monologues about what sort of life is worth living and how he can fix everything that fashion has destroyed. This will lead to the creation of a new Tiffany family full of true, moral people.

While Gertrude may yield her heroism to Trueman in the final scene, the audience is left to question whether the life he idolizes is the "right" way to live. He tells Mr. Tiffany to abandon their way of life: "You must sell your house and all these gewgaws, and bundle your wife and daughter off to the country. There let them learn economy, true independence, and home virtues, instead of foreign follies" (78). Should Mrs. Tiffany and Seraphina be sent away to the country to live in misery? By sending the women away to become independent and virtuous, Adam Trueman confirms that Gertrude is an ideal, true woman with cultural feminist traits. Will turning Seraphina and Mrs. Tiffany into independent women solve all of Mr. Tiffany's problems? My version of Gertrude certainly does not think so. As I discuss in Chapter 2 and 3, the adaptation process and my research on women's lives at the time has allowed me to build and perform Gertrude as the hero. I have emphasized her wit and desire to work and shown in rehearsals that she is the smartest person in the room. While my Gertrude still follows the rules and values her purity, she feels empathy for Seraphina and Mrs. Tiffany. However, she does not speak up and accepts the patriarchal rules set by Trueman. In our adaptation, Gertrude's reaction to being silenced is one of disbelief. It allows the audience to consider the patriarchal structure of a family and how Gertrude may have been better off on her own. 
Mowatt lived her life very differently from the world portrayed in Fashion. Her female characters end up following the rules or being sent away to the country to be remade into humble, true women. This ending, paired with her male hero, allowed the play to be a success. Societal standards supported this ending, and Mowatt claimed in her Autobiography that on opening night, the happy audience "loudly testified their approbation" (208). However, it was her independence and determination to support her family that allowed this play to be written. By moving to New York and becoming the main source of income for her household, Mowatt challenged traditional gender roles of the period and made herself a popular name amongst theatergoers. She gave us a radical piece of theatre that allowed women to work in plays that provided respectable depictions of women and make money in a patriarchal society. Because of Mowatt's hard work and refusal to stay in the home, Fashion can now be considered one of the first pieces of American feminist theatre. 


\section{CHAPTER TWO:}

\section{A LOVE OF INDEPENDENCE}

"My mother told me to be a lady. And for her, that meant be your own person, be independent." - Ruth Bader Ginsburg

While Chapter One explored Mowatt's life and feminist elements in her play, this chapter will dive further into Gertrude and her place amongst the historical moment she lives in that make her open to a cultural feminist reading. Gertrude is held up as the ideal woman at the conclusion of Mowatt's play and is rewarded for her good behavior with a marriage to the man she loves. Her appearance in all white and engagement at the end of the play initially led me to believe that she was nothing more than an advertisement for purity. After historical research into the period's gender codes and clothing, I discovered that she is much more. One way she can gain independence is to follow the rules and do as she is told. My Gertrude is a rebel though her rebellion is subtle. Gertrude fights against the patriarchal society of the time by being a woman with a job as a governess, dressing simply, and resisting the restraint that her clothing provides.

To prove that Gertrude was a cultural feminist at the time, I will examine the restraints placed on her as a working woman in nineteenth-century America and how she worked within them. I will also discuss the restriction of women's clothing at the time, as well as the work I did while wearing a corset to bring Gertrude's resistance to life in my performance, any emotion Gertrude is unable to show manifests in tugging and fidgeting with her clothing and displaying emotion with her fan. 


\section{What a Way to Make a Living}

An important aspect of Gertrude's character that supports a cultural feminist reading is her love for her job as a governess. Teaching was considered a respectable job for American women at the time and related to the cultural feminist value of women as matriarchs. Josephine Donovan explains that, "Underlying this cultural feminist theory was a matriarchal vision: the idea of a society of strong women guided by female concerns and values" (32). As a governess, Gertrude could teach Seraphina those "female concerns and values." My research into the role of a governess in an upper-class American household revealed that they were required to teach a plethora of subjects. A book of letters between an American governess and her student discussed the following topics taught in the house: literature, music, German, writing, and the Bible (Wharton and Bahlmann 28). Gertrude would need to be proficient in all of these subjects to secure her job and teach them to Seraphina. As she was raised in the country and had no city connections, Gertrude had to rely on her talents. Therefore, she probably spent most of her childhood learning these skills. Merely having the job of a governess shows that Gertrude is a hard worker and an educated woman at a time when only fifty percent of women knew how to read (National Assessment).

Gertrude's occupation did come with its share of rules and restrictions, which she embraces to continue working. Gertrude does not have total control of her life in the Tiffany household. She is considered a servant, even though she has more freedom than the maid Millinette. In nineteenth-century America, there were specific expectations placed on women working in upper-class homes. The Figure of a Governess from the British Library explains that, “The governess was expected to look after her pupils' moral 
education too. As well as reading the Bible and saying prayers with them, she was to set a good example of modest, moral behavior" (Hughes). While this quote comes from an article about European governesses, it matches the expectations I found in the aforementioned book of letters. Moreover, Mrs. Tiffany's embrace of European customs suggests that she would expect Gertrude to follow this standard and teach Seraphina "modest, moral behavior."

Since Gertrude would be expected to be a role model for Seraphina, she would need to be "on" in front of the Tiffany family. Working where she lives means that she is always on the clock. Gertrude's entire well-being depended on acting as the model young woman. These moral behaviors would be prescribed on every woman in the house. Christine Stansell explains in City of Women: Sex and Class in New York, 17891860, "mistresses believed that the working-class women who entered their sphere could only benefit from an experience of properly feminine ways. Victorian women saw moral reform in the home as their particular social responsibility" (156). Any unsatisfactory behavior from Gertrude as a "working-class woman" reflected on Mrs. Tiffany and her ability to fulfill her "social responsibility" of running a "moral" household. As running an upper-class home is a relatively new endeavor for Mrs. Tiffany, she is quite hard on Gertrude throughout the play, especially when Count Jolimaitre is around. Maintaining "properly feminine ways" requires Gertrude to embrace the constructs placed upon young women to further her career and gain independence.

Gertrude recognizing what is at stake for Seraphina and herself also allows her to be read as a cultural feminist. When she breaks the house rules and is discovered with Count Jolimaitre alone, Gertrude says to herself, "What shall I do? Ruined, ruined!" 
(Mowatt, Fashion 56). She understands that she has broken the moral code that Mrs. Tiffany has set, which will now lead to her "ruin." Before the Count's arrival, she kept herself safe in the Tiffany household by following the rules placed on her as a female servant. She thrived in a world where she had to set an example as a truthful, moral woman, supporting her being a cultural feminist. Her scheming to reveal the Count was a plan to save Seraphina, which is also a part of her job description. If one considers the "saving" done with Bible study, Gertrude was simply extending that duty to save Seraphina from ruin and upholding "female values and concerns" (Donovan 32).

\section{Let's Get Physical}

Etiquette in the workplace was not the only restraint Gertrude had to deal with. Women's clothing in the 1860s, when [Re]Fashion was set, was constricting and limited movement. Women wore eight layers of clothing at the time, including cage crinolines, boned corsets, and cumbersome skirts (Goldentul). Each layer of a woman's outfit served a purpose and protected their skin from the heavy fabrics used on corsets and dresses. After putting on a layer of undergarments, including a chemise (a long cotton shift), bloomers, and stockings, a woman would lace into an overbust corset (Goldentul). A tiny waist was desirable at the time, so women had the option to tight lace their corsets to take inches off of their waist size and displace their spleens in the process. (Oneill 12).

Consider Gone with the Wind when Scarlett O'Hara boasts of a 17-inch waist after being laced into her corset (Mitchell 76). For reference, the average women's size 8 in America has a 28 -inch waist. Lacing a corset too tightly could lead to a host of health issues, including stomach pains, vomiting, and fainting (Oneill 13). 
The corset was not the only item of clothing that would have restricted Gertrude's movement. After the corset was secure, a camisole would be layered over it and women would put on cage crinolines. These large metal skirts were used to give the wearer a bell-like shape, enhancing the corset wearer's tiny waist. They were made of metal rods that could break if the woman moved too quickly or sat down with enough force, resulting in cuts on her legs and waist (Oneill 13). Women were expected to move carefully in these cages, or risk injuring themselves. After the crinoline was secure, a petticoat would be placed over it to protect the clothes, followed by a woman's skirt and bodice. Daytime bodices usually included long sleeves and high necks that fit tight to the woman's body (Godentul).

Needless to say, an ensemble like this required a woman like Gertrude to consider her movements carefully. One of my first questions when looking at the corsets and crinolines was, "how did these women bend over if they dropped something?" Therese Oneill had an answer in Unmentionable: The Victorian Lady's Guide to Sex, Marriage, and Manners: "A woman who is not of the working class doesn't have much reason to bend over in the nineteenth-century. And if she does, a lady lowers herself... by bending her knees" (13). While Gertrude is a working woman, she would be dressed as a "lady" to represent purity in the home. She would be seen by company and around town with the Tiffany family, so her clothing needed to resemble Mrs. Tiffany and Seraphina's style. Due to Gertrude's status as a servant, her clothing would be less fashionable than Mrs. Tiffany's. This is noted in Gertrude's costume requirements that are offered at the beginning of the play: "Second dress: Ball dress, very simple" (Mowatt, Fashion 9). While she would still have the appropriate silhouette for the ball, Gertrude's gown would 


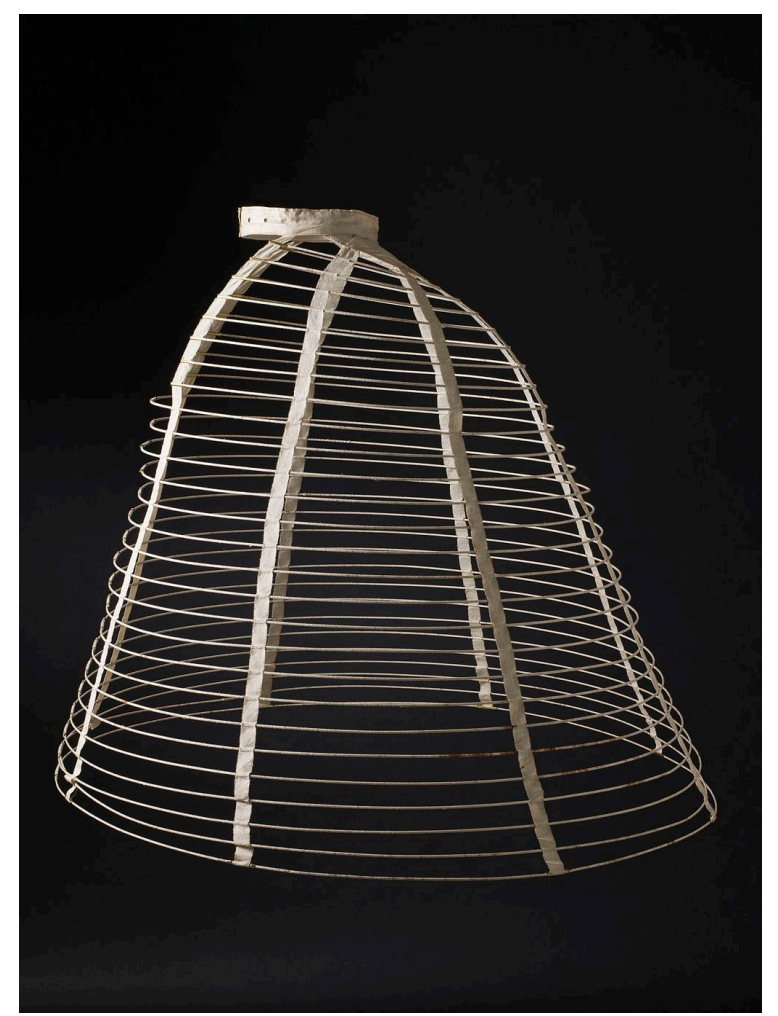

Figure 1. A nineteenth-century cage crinoline (Oneill 14).

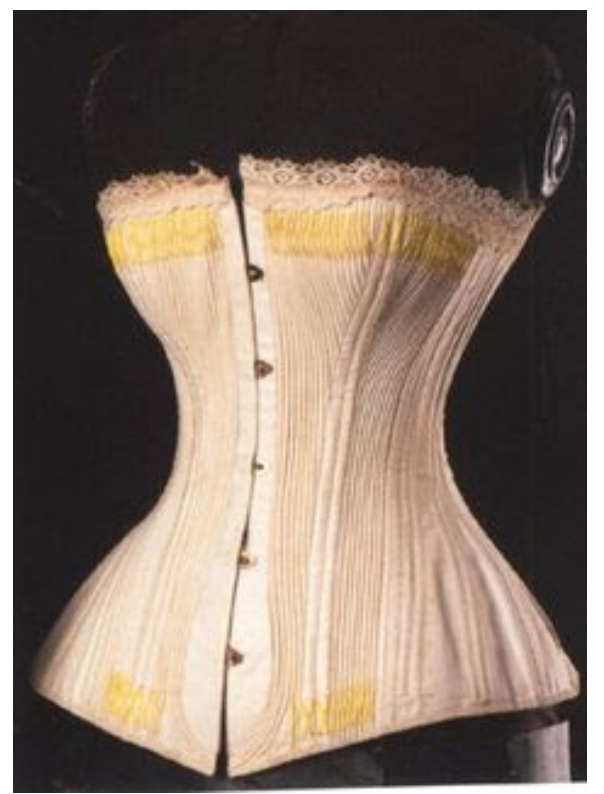

Figure 2. A nineteenth-century overbust corset (Oneill 14). 
not carry any of the adornments seen on Seraphina or Mrs. Tiffany. The klutz in me panicked a bit when I considered my past use of a crinoline in A Christmas Carol. I tripped over the ruffle and large skirt, sending myself flying across the back of the stage in front of 1,200 people. "I do not think I would be a lady of fashion" (3), I solemnly wrote in my journal.

Another cultural feminist virtue that Gertrude embraces through her clothing is purity. An element of the script that I became slightly obsessed with was Gertrude's description when she enters. The stage directions read, "The interior of a beautiful conservatory; walk through the center; stands of flower pots in bloom; a couple of rustic seats. GERTRUDE, attired in white, with a white rose in her hair; watering the flowers" (25). During my first few readings, I scoffed at this description. I complained in my journal, "White? She's wearing white? How unsubtle can this be? She might as well have a sign across her forehead that says VIRGIN" (1). I did not want to play the girl in white, and I thought it cliche. I did not even wear white at my wedding. How could I find something in common with this character? The flower imagery seemed over the top. Female genitalia has often been associated with buds and blossoms, and the loss of virginity is called a deflowering. Gertrude's engagement with flowers is nurturing and validates the cultural feminist idea that women should represent a "matriarchal vision" (Donovan 32). A line from The King and I which, like our adaptation, is also set in the 1860s, compares women to flowers, “A woman was made to please man. A man was made for woman to please. A man is like the honeybee, to fly from blossom to blossom, a honey bee must be free, but blossom must not ever fly from bee, to bee, to bee" (Rogers 
and Hammerstein). A "white rose in her hair" was another sign to the audience that Gertrude was a "good girl" and saving herself for marriage.

In an attempt to curb my judgment and understand the white clothing through the lens of cultural feminism, I started to look at paintings of the period and noticed a pattern. All of the young women in these paintings were wearing white. In Claude Monet's 1866 painting Women in the Garden, several young ladies gather outside in white or sporting white accessories. Perhaps I was too critical of the white. Oneill explains that white was a popular color for women to wear because it allowed them to show "their delicacy and careful natures" (49). By wearing white and keeping it pristine, women let the world know that they took themselves seriously. Gertrude needs society to take her seriously because she has no family name or money. Keeping her white clothing clean was a cultural feminist act because it showed that Gertrude had "careful natures" and was fostering feminine traits. By wearing white, she is being a good role model for Seraphina.

\section{The Language of Rebellion}

Part of observing Gertrude with the idea of cultural feminism required me to consider restraints and rules in my performance. Gertrude spends a lot of time on stage in silence, which I struggled with in the beginning stages of rehearsal. I especially struggled with her silence in Act IV, when Gertrude is discovered in a dark room with Count Jolimaitre and immediately sent away. When he insinuates that Gertrude's intentions were not entirely innocent, Mrs. Tiffany hurries to defend her home in front of him: "Get out of my house, you owdacious--you ruined--you abimi young woman! You will corrupt all my family. Good gracious! don't touch me,--don't come near me. Never let me see your face after to-morrow. Pack" (61). Even though Gertrude is found fully clothed in a 


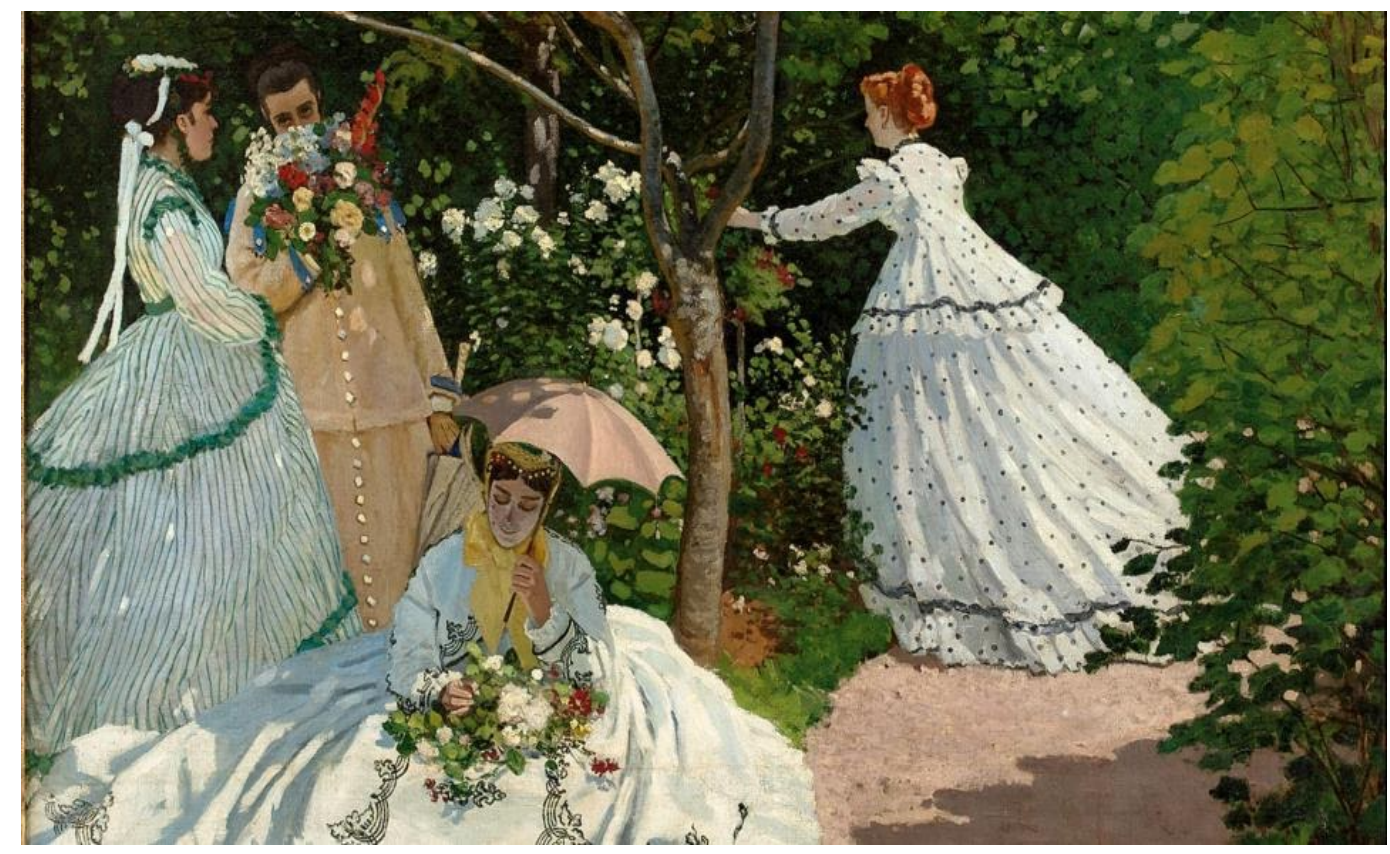

Figure 3. Claude Monet's Women in the Garden, which I used to examine the common use of white in women's clothing. 
separate area of the room than Count Jolimaitre, the worst is expected of her while he gets off scot-free. Gertrude is considered a "ruined" woman that will "corrupt" the household because she is alone with a man. As Mrs. Tiffany is trying to find a husband for Seraphina, she needs her home to appear moral. Gertrude has no standing to interrupt or defend herself at this moment. Her one attempt to explain herself to Mrs. Tiffany is met with an interruption from Adam Trueman:

GERTRUDE. Mrs. Tiffany, Mr. Trueman, if you will but have patienceADAM TRUEMAN: Patience! Oh, Gertrude, you've taken from an old man something better and dearer than his patience--the one bright hope of nineteen years of self-denial--of nineteen years of--[Throws himself upon a chair, his head leaning on table] (61).

Upon first reading this scene, I found myself frustrated that Gertrude did not defend herself. In this scene, Gertrude is still unaware that Adam Trueman is her grandfather, yet she does not respond to his insistence that she has taken something from him. However, speaking out of turn could come off as forward or rude. In a conduct book from the nineteenth-century, The Polite Ladies' Guide to Proper Etiquette, I discovered this rule: "Still, however, it is certain, that young ladies should be more apt to hear than to speak" (97). The above exchange is one of Gertrude's first attempts to defend herself. As she simply asks for "patience," she is immediately cut off and denied her voice, leaving her to "hear" instead of "speak." Gertrude often stays quiet whenever Mrs. Tiffany is in the room as is first noticeable in Act II in the garden. In the scene, Count Jolimaitre suggests that Gertrude has been talkative, resulting in Mrs. Tiffany exclaiming, "I am shocked at the plebeian forwardness of this conceited girl" (30). Mrs. Tiffany does not know what 
Gertrude has said, but she assumes that it was "forward," and that Gertrude must be "conceited" for daring to talk to a Count.

Finding Gertrude's rebellion in silence took a closer look at forms of rebellion of the period. I was lost during the scenes where Gertrude needed to follow the Polite Ladies' Guide to Proper Etiquette and be more "apt to hear than to speak" (97). My facial reactions gave away that I thought the situations unfair. I had to remember what is at stake for Gertrude if she is too emotional in front of her employer. During the first month of rehearsal, I wrote in my journal, "Gertrude needs stakes in every scene. There's that damn word again, stakes. WHAT ARE THEY ON A COMPUTER SCREEN? I am frustrated, but this play cannot be about frustration" (4). Gertrude has to represent the ideal young woman to keep her job. Society's rules at the time told me that I could not make my exasperated faces. If independence is Gertrude's goal, which she insinuates when she says her form of mania is a "love of independence" (26), she has to behave as society expects. If she loses her job, she loses her independence. There can be no arguing or grand speeches about why she has been wronged. Knowing the rules and how to obey them is Gertrude's brand of feminism. Cultural feminism embraces what it imagines as innately feminine virtues, which Gertrude displays when being moral and quiet in the house. This brand of feminism is different than mine and that is okay. Jordan gets to make faces when she is upset in public; Gertrude does not.

Though Gertrude tries to follow the rules in the play, I wanted to find a way to show that she still fights against them when frustrated or nervous. Gertrude may not be the most fashionable character, but she does know how to move and address the restraints in her clothing. She manages to take care of the conservatory and teach piano lessons 
without letting her clothing get in the way. While I knew that Gertrude would wear the proper shapes and undergarments, I wondered how she might fight against the constriction that clothing provided. She talks about the "heated air of the conservatory" (27), and I considered the tugging of necklines people tend to do when they are overheated. My costume included a very high neck and long sleeves that tightened at the wrist. I started playing with pulling at the neckline and wrists of my top when Gertrude is nervous or overwhelmed. A scene where I showed this was in Act I scene i where Count Jolimaitre enters and throws the house into a tizzy. As Count Jolimaitre lists his many accomplishments and insults Americans, I found myself wanting to roll my eyes. This action did not feel acceptable for Gertrude to do, so I channeled the energy into toying with my sleeves' cuff. Subconsciously, she is fighting against her clothing. She accepts feminine fashions and keeps them simple; yet, she indicates her resistance to them in these subtle ways.

In rehearsal and Dr. J. Ariadne Calvano's Period Movement class, I started working in a corset to figure out what my movement and breath would feel like. My corset had mesh in between the bones, so there was more stretch than a traditional corset would have, but it still provided valuable insight. When in the corset, I could not bend forward, and any full-body movement caused me to be out of breath faster than without the corset. I considered how this might affect Gertrude's work in the conservatory. The lack of movement and deep breath would make taking care of plants difficult. I decided any physical activity she did, and the use of her gardening tools would need to be slow and precise. Gertrude would need to learn to do her work right the first time or she could tire quickly. The corset also encouraged the use of her hands to expel energy. Since deep 
breaths weren't possible, when Gertrude was upset in the closet scene and the letter writing scene, I used the wringing of my hands as a soothing mechanism. The corset effectively made it impossible for her to be too over the top physically.

Another vital element of Gertrude's rebellion against the expectation to be quiet and polite was the use of her fan. During my time in Dr. Calvano's Period Movement class, I learned about Jean-Pierre Duvelleroy's fan language, which he developed after spending time in Queen Victoria's court. This language was printed on a leaflet and distributed to women. It grew in popularity in the United States in the mid-nineteenthcentury (Cale). I was immediately drawn to it, as I thought it would be a subtle way for Gertrude to express her feelings without using her voice and would expand on the energy I was discovering in my hands. I considered the many statements that could be said with the fan and went through my script to mark areas where I thought the movement might be beneficial. Since Gertrude is new to the fan language due to her country upbringing, I focused on using "yes," "no," "I wish to get rid of you," "I hate you," and "I love you." It took a lot of practice to make these movements subtle, as anything too large would distract on the Zoom screen. Besides the set language, I worked on using Gertrude's fan as an extension of her feelings. When she confesses her love to Colonel Howard in Act $\mathrm{V}$, her fluttering is small and fast, mimicking the excitement of her heartbeat. However, when Count Jolimaitre arrives in that same scene, she slams the fan shut quickly and uses it to point and "poke" him. Her voice stays polite when dealing with the imposter Count, but her fan does not. It would be inappropriate for her to be loud or overly emotional in front of the household. By using her fan as an extension of her feelings, Gertrude can speak her mind in a manner that is deemed proper. 


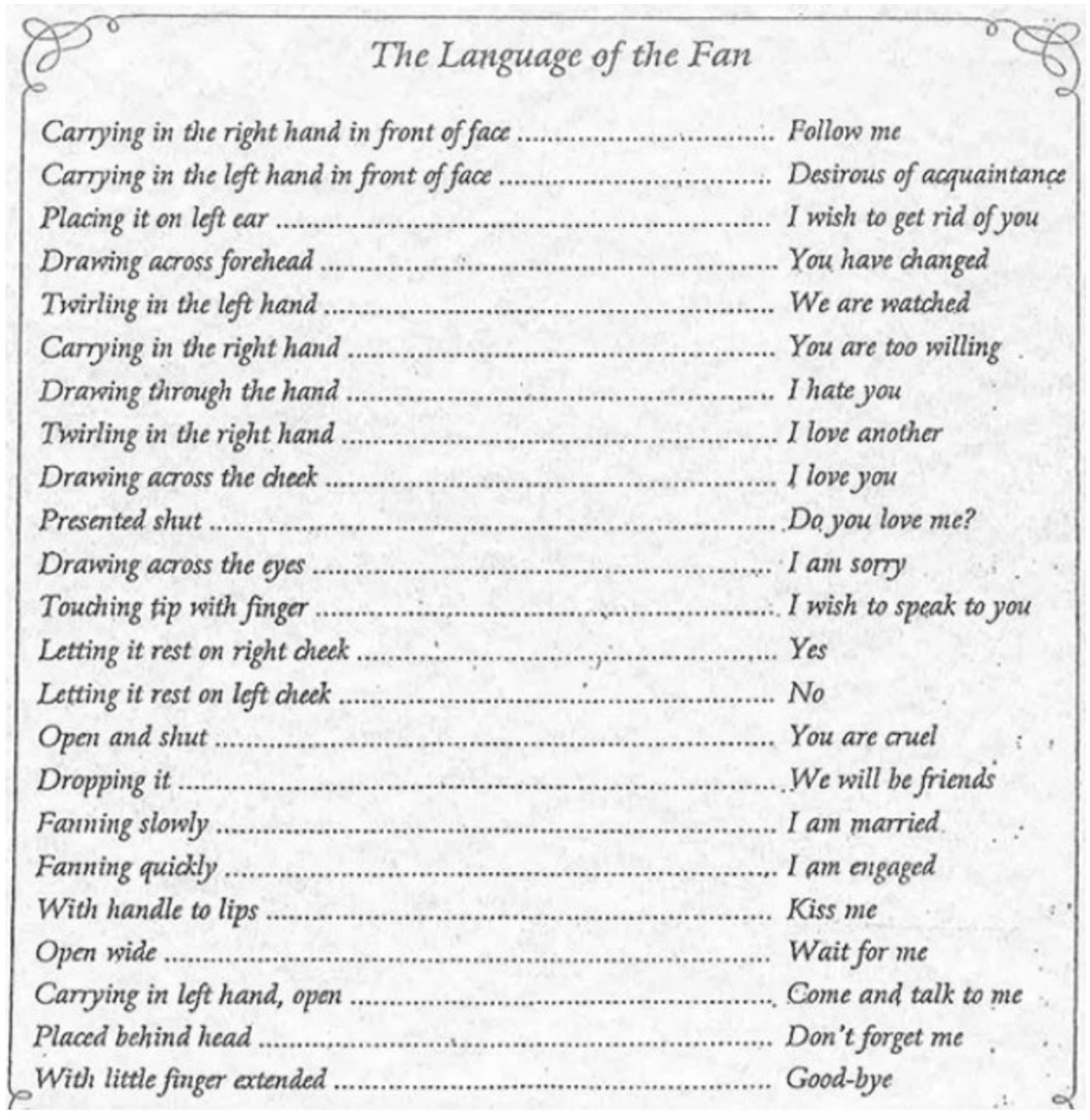

Figure 4: Jean-Pierre Duvelleroy’s fan language that I used in my performance. 
Gertrude's rebellion is understated but still based in cultural feminism. Donovan says that cultural feminism "[affirms] that feminine qualities may be a source of personal strength and pride" (31). Gertrude is proud of her accomplishments and the life she has built for herself. She even refuses to cry when it is taken away from her stating, "I should be weeping. If pride had not sealed up my tears" (Mowatt, Fashion 60). She does not step out of the bounds of her role as a young woman in this world; instead uses what were then imagined as natural abilities as a woman to make a better life for herself. Even though society and her clothing are restrictive, she blossoms by embracing the limitations. This results in a well-deserved happy ending for her and an exclamation that virtue is her own reward. Dolan explains that the coded as feminine virtues of being truthful, quiet, and pure are "desirable" to cultural feminists (6). Gertrude is a cultural feminist because she uses these gendered virtues to gain independence instead of fighting against them. 


\section{CHAPTER THREE:}

\section{REDESIGNING WOMEN}

"It is not a failure to readjust my sails to fit the waters I find myself in." - Mackenzi Lee,

\section{The Lady's Guide to Petticoats and Piracy}

This chapter will explore the adaptation process for the online production of the University of Louisville Theatre Arts Department's production of [Re]Fashion, which took place over Zoom at the end of January 2021. It will focus on the struggles of adapting Fashion for a digital world and retelling the story for a modern audience. Not only were the cast and creative team adapting the script, but we were also adjusting to working entirely online. The switch to online acting initially caused me to retreat into my head and question if I was even doing theatre. While the process was complicated at first, revisions to the adapted script allowed me to suggest changes for lines and scenes that eventually led to a stronger and more resilient Gertrude, while her relationship with Professor Reddi Turner supported her feminist disposition.

To show this, I will first discuss the roadblocks I encountered during the first few weeks of rehearsal and the steps I took to get out of my head. My time figuring out how to work on Zoom allowed me to consider how I present my femininity. This led to a deeper connection with Gertrude and a better understanding of the restrictions she lives with. I will also present the additions and changes I helped make in the script, which encouraged me to give Gertrude more confidence. Dr. Calvano added Gertrude to two scenes in which she did not appear in the source text. These additions helped me explore 
Gertrude's position in the house, her relationships with other characters, and a more robust conception of her personality. Finally, I will examine Gertrude's relationship with Professor Reddi Turner, an added character who functioned to narrate and critique Mowatt's plot and characters. In the adaptation, Gertrude is the first character to hear and speak with the Professor. Their relationship gives Gertrude an outside perspective and encourages her independence.

\section{The Struggle Bus}

Adapting to Zoom acting was a difficult step that allowed me to relate to the restrictions Gertrude faced. As the production is officially over and I have a full rehearsal process and run under my belt, I can honestly say that I would like this pandemic to be over. Acting via my webcam is not something I would like to do ever again. To quote my favorite reviewer, my mother, "You were in the room all alone? That seems hard. I guess y'all did pretty good, considering" (Tudor). I struggled, especially during the first month and a half of rehearsal. Often, I would turn my camera off during exercises and have fullblown panic attacks. I felt no connection to my castmates, and I was constantly body checking, which is a compulsion that includes checking one's appearance. Since I could see myself in Zoom, I would check my image to make sure my double chin was not showing or that I raised my eyebrows to make my eyes look larger. I was self-conscious about playing a love interest written to be younger than I am, and there are several lines in the play that call Gertrude attractive. Adam Trueman's reference to her "girl's soul" and "fair" look indicate her age and beauty (Mowatt, Fashion 61). I started to obsess over how the audience might judge me if I could not present as a pretty young woman. I attempted to curb this by turning my image off on screen, but I discovered I had to see 
myself so I could place props, and the broadcasting system our tech crew was using required everyone's screen to be on at all times. This led to a lot of stress in the rehearsal room, and I had a hard time shaking it off in a healthy way. I journaled about the difficulties I had leaving rehearsal, "I have got to figure out a way to destress after these rehearsals that doesn't include scream-singing 'You Oughta Know' in the car on the way home. It's really hurting my voice" (Haggard 5). Losing my voice was not an added stress I needed in this process.

My fixation on how I looked while acting manifested in stubbornness, a trait I ended up enhancing in Gertrude. Before this production, any judgment of my appearance lived in my head, but I could usually connect with my scene partner and forget it. Working on Zoom made it impossible for me to do that. Now I could see what every emotion looked like on my face, and I had no way to look my partner in the eye. My journal from the first month of rehearsal was full of questions, "I feel lost in group scenes, where do I look? At the camera? At my partner? I feel frozen" (Haggard 6). As a feminist, I did not approve of this preoccupation. Gertrude is so much more than her appearance (as am I). My gender felt too present on Zoom. I continued to think about a quote I read in Women in the American Theatre: Actresses and Audiences by Faye E. Dudden. Dudden states, "The woman who acts is thus inherently liable, whatever her own intent, to become the object of male pleasure" (3). I had brought this quote into my acting class last year and argued that my gender should not matter in my performance. Being labeled an “object” on stage seemed insulting. Why couldn't my work and talent be acknowledged before my gender identity? Jill Dolan discusses this power dynamic as well, stating, "the one-way nature of the male gaze, owned by a spectator who is 
obscured in a darkened theatre, specularizes the female body, which is not allowed to gaze back" (130). This is a similar struggle to what Gertrude faces in the play. She is talented and good at her job, but her treatment boils down to being a woman. She cannot "gaze back" at the Count to make him feel uncomfortable in the conservatory or she risks being fired. She has to accept it like I had to accept that some audience members may judge my appearance. While my stakes are not as high as Gertrude's, I related to her when I was on Zoom. I recognize that the obsession with my appearance on screen represented a patriarchal standard of beauty that the theatre world has often reinforced. My performance acknowledged that while male characters in the play found Gertrude attractive, it was never something Gertrude worried about. As long as she presented as neat and tidy, Gertrude was happy with her appearance. Having Gertrude not care about her looks gave me back my power.

These insecurities led me to uncover a physical motion for connecting with Gertrude's strength. After a particularly rough evening in rehearsal, which ended with me hyperventilating on the floor, Dr. Calvano called me to see what was going on. I explained that I felt entirely alone and that this did not feel like acting anymore. We discussed different ways to find that connection with my partners. They suggested focusing on my partners' faces while finding a physical gesture that I could do when I was feeling a disconnect. Performing this gesture was a way for me to signal to myself that I needed to refocus. Since I was doing a lot of fan work and expressing energy through Gertrude's hands, I decided to make a fist. By squeezing my fingers against my palm, I was essentially crushing my judgment while quickly signaling to myself that I needed to get over it and do my job. This gesture worked, and I was finally able to start 
acting again. By quelling my fears, I was able to relate to Gertrude's life by comparing my restrictions on Zoom to the limitations she faced from her clothing and the societal rules of nineteenth-century America. I focused the energy that I was holding in my chest on my acting work. My Gertrude would not have cared if someone was judging her appearance. She is proud of herself. Making that fist was a reminder that I belonged in the role and that Gertrude was stronger than I initially gave her credit for.

\section{Adding and Subtracting}

Now that I could stop hyper-fixating on myself, I was open to considering Gertrude's relationships and her place in the Tiffany home to strengthen her feminist streak. One evening when I was working with assistant director Blair Potter and Emma Lauter, the actress who played Seraphina, we realized that their relationship was not represented in the source text or the adaptation. Gertrude calls Seraphina "a friend" and suggests that her plan to reveal Count Jolimaitre comes from saving her: "to convince Seraphina would be equally difficult, and her rashness and infatuation may render her miserable for life. No--she shall be saved! I must devise some plan for opening their eyes. Truly, a woman can fashion a means especially to punish a villain or to shield a friend" (Mowatt, Fashion 49). Gertrude and Seraphina only share two scenes in Mowatt's original script and never speak to one another. Dr. Calvano could have combated this on a normal stage by placing us next to each other and assigning business that created a relationship, yet it was not so simple online.

Exploring Gertrude's relationship with Seraphina reinforced her rebellion and desire to expose Count Jolimaitre. Dr. Calvano acknowledged that their lack of stage time together was a problem and decided to add me to two scenes that include Seraphina: Act I 
scene i and Act III scene i. I would enter with her to make it appear that we had been together in another room. At first, I mourned my breaks because now I had no time to eat snacks during the show. Meanwhile, I realized it would be helpful to be included in these scenes to work on Gertrude's "working" persona. In these scenes, I would react anytime Mrs. Tiffany commented on Seraphina's dress or manners, as those would be Gertrude's responsibility. When she orders Seraphina to arrange her dress for the Count's entrance, I would motion to Emma to fix her collar and examine the skirt and sleeves to make sure Seraphina looked orderly (8). I also did a lot of backstory work about Gertrude's relationship with Seraphina. Gertrude is an orphan and grew up the only child in her home. Having Seraphina to talk and relate to was vital for me to think about; Gertrude would not want to save her if she did not care about her. While their relationship may have been entirely in my head, it influenced how Gertrude felt about Count Jolimaitre and the Tiffany family.

A change in the quote above allowed Gertrude's resistance to escalate. In the final draft, it became, "to convince Seraphina would be equally difficult, and her rashness and infatuation may render her miserable for life and leave me a governess in the Count's household. No--we shall be saved" (Calvano et al 39). This new line in the monologue implies that Gertrude will continue to be Seraphina's governess, which will require her to continue to dodge the Count's advances. If Seraphina marries him, Gertrude may be faced with the choice to yield to him or quit her job. The change from "she shall be saved" to "we shall be saved" shows the women as a unit, a "we." This implies their friendship while upping the stakes for Gertrude. If the characters are seen as women working together, this relationship can be used to emphasize cultural feminism in the 
play. They are working to save the feminine trait of virtue. Gertrude must plan to help her friend and herself, which gives her power over her story and supports her decision to trap the Count in Millinette's room.

Part of the adaptation process was rewriting scenes and character interactions which helped give Gertrude a more prevalent voice. Dr. Calvano and production dramaturg Dr. Segal had told me I was free to suggest line additions or changes to these new scenes. At first, I did not think my opinion would be helpful and kept any ideas to myself. During a meeting with Dr. Segal, she suggested I get over that feeling and send the creative team my additions. What was the worst thing that could happen? I started small with my suggestions. In Act I scene $i$, the suitor and poet Mr. Twinkle arrives to call on Seraphina. As he attempts to recite a poem the women in the room repeatedly interrupt him. Later in the original text and the adapted version of the play, Mrs. Tiffany's sister Prudence tells Adam Trueman that Gertrude is in love with Mr. Twinkle. This idea comes out of thin air because Gertrude is not usually in the room when Mr. Twinkle arrives. I found it essential to have her acknowledge him in front of Prudence, so the idea makes sense later. It also strengthens the joke in the scene. None of these women want to hear this poem, so Gertrude jumping on the bandwagon to interrupt him fits. I suggested the line, "That's lovely, Mr. Twinkle," as an interruption (7). This line would give Prudence her ammunition and allow Gertrude to interact with the scene and show that she does have a voice in the house. I initially thought of this line as an add on to the joke, but it broke Gertrude's silence and showed that she was listening and reacting to the world around her instead of just sitting quietly. 
Examining Gertrude's rank in these new scenes fleshed out the historical research I had done and allowed me to consider how being polite and proper embraced cultural feminism. I knew that she needed to be on her best behavior around Mrs. Tiffany because she was always on the clock. However, I still had to engage as an actor and react accordingly. Count Jolimaitre is present in both scenes with Gertrude and Mrs. Tiffany, and Mrs. Tiffany would expect everyone to cater to him. I stood in a small bow upon the Count's entrance, with my forehead and eyes down. This was Gertrude's servant posture and often showed up when Mrs. Tiffany entered a room. Still, after her encounter with the Count in the conservatory, Gertrude does not bow to him again. I made it a point not to acknowledge his title after he insults her, strengthening her journey for me. It is a small detail, but it helped me recognize Gertrude's pride. Her rank was also evident in Act III scene i when Dr. Calvano added a bell for Mr. Tiffany to ring and call Gertrude into the room. This entrance was humbling and made me feel self-conscious for most of the scene. I spent a lot of time working on my fan language here, hiding my face and tapping my cheek to say "no" to the Count whenever he spoke. The adaptation process can fluctuate, and I ended up being removed from this scene five days before opening night. The technical aspect of getting my box on the screen was too much for this large scene, so I said my lines off stage instead. I wrote in my journal that evening, "All of those rehearsals working on my body language and fan work seem kind of pointless now. I suppose I should look on the bright side and take this time to sit and rest during the show" (15). Looking back, I realize that the rehearsals were not pointless. They allowed me to work on Gertrude's role as a servant and my comfortability with the fan language. I did grow to appreciate this break, as my shoes were not comfortable. 
My most considerable contribution to the overall arc of the play came late in our rehearsal process and added to Gertrude's feminist stance. At the end of the show, she becomes engaged to Colonel Howard. This conclusion had always rubbed me the wrong way because I felt it was a Disney princess ending and went against Gertrude's "love of independence" (Mowatt, Fashion 26). While I knew she loved Colonel Howard as she tells him, “And truly, I love you, Colonel Howard” (Calvano et al 55), I also knew she loved working. In their first scene together, she says of her employment, "I had abilities and desired to use them" (Calvano et al 19). If Gertrude did not enjoy her work, she could have stayed in Geneva to tend a garden there. But she "desired" to use the "abilities" she had worked so hard to learn. Marrying the Colonel would mean moving away from her job. I had kept quiet about this because it is a standard dramatic device. Comedies end with a wedding. One night in late November, while we were rehearsing the final scene, Dr. Calvano asked how I felt. They meant how I was feeling about the blocking and motivation, but I blurted out, “Frankly, I really hate this. I don't want her to marry him.” This confession managed to stop everyone in their tracks, and we decided it would be best to take a break while Dr. Calvano thought about what I had just said. In my ideal world, Gertrude would not have a love interest in this play at all. I imagined her pulling a Jo March and opening up a school for girls. However, it would have been quite rude to ask Dr. Calvano to write out a character to be played by another actor. Asking to rewrite the proposal seemed like a better option. The actor playing Colonel Howard, Sa'id Kelly, disagreed with me. He felt an engagement was the proper ending for the couple. In an attempt to appease us both, Dr. Calvano suggested changing the line from "Gertrude, my love, will you marry me?" to "Gertrude, my love, will you have me?" (54). The word 
"have" makes it Gertrude's choice and sets them up as equals. Replacing "marry" with "have" left the ending open to interpretation and allowed me to live Gertrude's single girl fantasy.

\section{The Professor Is In}

Gertrude's relationship with aspects of the play outside of the Tiffany home provided a secure place for her to show her resistance. In my initial vision of the character, I had imagined that asides assigned to Gertrude in earlier drafts of the adaptation would allow her to speak her mind to the audience. These lines would reveal her strength and wit. Unfortunately, most of these asides ended up on the cutting room floor, so I turned my attention to Gertrude's interactions with different characters. I had routinely discussed with Dr. Calvano and Dr. Segal my absolute hatred for the ending and Adam Trueman's takeover of the action in Act V. I noticed in Mowatt's original script, all of the women go silent. Only Millinette drives her story's conclusion by asking Count Jolimaitre, revealed to be Peter Gus Treadmill, to marry her, which she has to do because she is now out of a job. I thought I would just have to accept the finale that Mowatt wrote, but Dr. Segal reminded me that anything was open to change.

While actress Brandi LaShay worked more on her character, Professor Reddi Turner, it became clear that the Professor would become an ally for Gertrude and help amplify her voice. Once the Professor reveals herself to Gertrude in Act IV, she starts to aid Gertrude in the quest to fool the Count. She keeps watch for Gertrude outside of Millinette's room and warns her when the Count is coming. The Professor has been Gertrude's cheerleader since Act III and celebrates when Gertrude figures out the Count's plan: "Well, at least someone sees through his facade. Fashion away, Gertrude, re-fashion 
your way" (Calvano et al 38). By having the Professor on her side, Gertrude can get Count Jolimaitre out of the supper room and into Millinette's room. The Professor also helps Gertrude tell her side of the story after she is found in Millinette's room with the Count. Mrs. Tiffany fires her and Gertrude frets over what to do. In our production, the Professor connects with Gertrude at this moment and hands her a pen and paper so she can write her account of the previous evening. By handing Gertrude the tools she needs to tell her story, the Professor is helping her right the wrongs committed by the Count the previous evening. This relationship gives Gertrude confirmation that her resistance has not been in vain. As the Professor acknowledges everything that Gertrude has been thinking, Gertrude becomes bolder with her reactions. To start the scene, Brandi and I would make eye contact, and I would give the Professor a brief nod to let her know that I understood what she wanted me to do. This letter leads to Adam Trueman and Colonel Howard realizing that Gertrude was telling the truth, propelling the rest of the characters into learning Count Jolimaitre is an imposter. In this scene, the Professor helps Gertrude save herself.

The Professor could do what Gertrude could not in some moments and roll her eyes or give an exasperated sigh. In Chapter One, I argued that Gertrude is the would-be hero of Mowatt's play. Professor Reddi Turner is the hero of ours. While the Professor was present during the entire show, she chooses when characters can hear her. Because Gertrude can hear her during this scene, I got to react to what the Professor was saying. In Act V Scene i, Trueman starts to speak for Gertrude, but the Professor cuts him off: ADAM TRUEMAN. You needn't--she'll forgive you. You don't know these women as well as I do-- 
PROF. REDDI TURNER: Enough moral proselytizing from Mr.

Trueman! You need lessons in listening. Let us retire to the Tiffany's drawing room for results and perhaps revisions (Calvano et al 51).

As Trueman insists that he knows the women in the house better than Colonel Howard, the Professor switches his words around to ask him to be quiet. By taking Trueman's "you needn't" and saying, "you need to," the Professor is seizing the narrative away from him. While I tried to keep Gertrude's reaction here subtle, I did find a moment to look "up" at the Professor (she lived at the top of the screen during the broadcast), smile, and then nod in agreement. Gertrude would have liked nothing more than to tell Mr. Trueman to let her handle her affairs at this moment, but that would have been out of turn. The Professor can come to her defense and speak what Gertrude cannot.

Professor Reddi Turner reexamines the end of this play and interprets it for a modern audience. This gives Gertrude a feminist ally and emphasizes Gertrude's resistance. Gertrude can agree with everything the Professor says from outside the frame of the action that she cannot say herself as a female servant within it. The audience can see their connection and know that the Professor is providing Gertrude with support. The Professor takes back the power at the end of the play after Adam Trueman tells Gertrude to be quiet. She tells him, "Who said we needed your voice to settle this matter? Let's hear from someone else, shall we?" (Calvano et al 59). While Gertrude does obey him, the Professor's interruption shifts the perspective and permits Gertrude to consider another voice. The Professor's interludes made room for the audience and characters to reflect on why everyone was allowing him to take over. 
As an actor, I have always had an adaptation of the story I am telling in my head, but this was the first time I could alter the script's actual words. I felt my contributions were small, but they did help broaden Gertrude's story for me and possibly the audience. The text and story elements I added gave her voice more presence and upped her stakes. Gertrude's connection with Professor Reddi Turner provided a female ally and friend that is not present in Mowatt's original script. The past year has been one of adjustment, so it only made sense that I would need to adapt to performing this piece. I had to accept my wins and losses along with Gertrude's. The process of discussing my likes and dislikes of the story with the production team helped shape my character's overall arc. While Gertrude does not end the play a single woman with a school of her own, she does end it with a new family and pride intact. In her final monologue, the Professor tells the audience to "take up action to create your own resolution" (Calvano et al 62). Spurred on by the Professor, Gertrude takes action at the end of the play to reveal the Count and confess her love to Colonel Howard. As she has now had her eyes opened by the Professor, Gertrude can continue her journey toward true independence. 


\section{CHAPTER FOUR:}

\section{COMPOSING GERTRUDE}

"The actor must know that since he, himself, is the instrument, he must play on it to serve the character with the same effortless dexterity with which the violinist makes

$$
\text { music on his." - Uta Hagan }
$$

This final chapter will investigate different techniques I used to connect to the mid-nineteenth-century and Gertrude. As explained in Chapter Three, I struggled in the beginning stages of rehearsal to see anything other than a computer screen and an empty room behind me. While Chapter Three discussed text and story changes that helped me build a stronger Gertrude, this chapter will explain how my acting process contributed to bringing that Gertrude to life. I discovered that Grotowski rivers, image work, imagination exercises, and attention to my voice helped me feel more connected to our script and the world of the play. This connection permitted me to embrace Gertrude's femininity and enhance her cultural feminist presence in our production. Images and imagination exercises helped me create the Tiffany home and a mid-nineteenth-century aura in my workspace, while Estill voice work allowed me to heighten my natural pitch and musical traits in my speaking voice.

A lot of these discoveries were made during Dr. Calvano's Period Movement class in Fall 2020. In this class, I was able to use Grotowski rivers to explore pieces of art from the period. This helped me embody a mid-nineteenth-century American woman. I also used Stella Adler's imagination exercises to construct the Tiffany home in my mind 
and focused on embracing music in my voice as a means to relate to Gertrude. In my experience, male directors and acting teachers have asked me to exaggerate or stifle my femininity because they did not agree that it related to their perception of socially constructed feminine traits. By using exercises presented by female or non-binary teachers, I could feel safe exploring femininity without judgment. The methods I used could be beneficial for actors that are trying to relate to dated characters from period pieces and modernize their performance.

\section{Painting Actions}

During the Fall of 2020, I took Dr. Calvano’s Period Movement class which helped me discover how Gertrude moves within the world of the play. Each student picked a character from the mid- $19^{\text {th }}$-century to work on in this class, and I chose Gertrude to further my physical research for my thesis. An element of Dr. Calvano's course included performing Jerzy Grotowski's "rivers" while working with images from the period. Rivers are a flowing movement exercise created in Poland at the Theatre of 13 Rows during the 1960s. A river allows an actor to focus on sensation and actions in the body to get out of their head. The flow refers to the non-stop actions of the exercise which require the actor to be in constant movement. Rivers include using what Grotowski called the "plastiques," which I define as the use of external stimuli to develop isolating movements of each joint in the body. For example, If I felt like an image or piece of text resonated in my hips, I would explore any movement I could do with just my hip joints. In class, students would bring in images and do rivers in response to them while wearing mid-nineteenth-century clothing. Dr. Calvano provided the class with a non-binary view of Grotowski exercises and made them available for students of all gender identities. 
They did not suggest or insist that specific genders should explore certain movements, but instead opened up all sensations for us. For instance, while I may prescribe wide legged, large movement as "male" or small, graceful movements as "female" by society's standards, Dr. Calvano encouraged us to think about moving any way we could based on images and text. We would then pair it down to fit the societal structure of the period. This helped me stop judging my movement. Instead of approaching Gertrude's movement within a set gendered expectation, I explored all options presented and decided which areas of the body felt the most comfortable for Gertrude.

To find movement and resistance to societal expectations in Gertrude's text, I spent time in Dr. Calvano's class working with two main images. The first image was The Irritating Gentleman (1874) by German painter Berthold Woltze. In it, a young woman sits on a train in her mourning wear, an exhausted expression on her face. Behind her, a man leans over the seat towards her from behind, invading her space and talking to the back of her head. It immediately reminded me of Gertrude's first scene alone with Count Jolimaitre, in which he occupies her space:

COUNT JOLIMAITRE. Sharp as ever, little Gertrude! But now that we are alone, throw off this frigidity, and be at your ease.

GERTRUDE: Permit me to be alone, Sir, that I may be at my ease! (Mowatt, Fashion 27).

Similar to the young woman in the painting, Gertrude just wants "to be alone." The woman in the image seems to be leaning as far away as she can while still seated. Her back is straight, and her gaze is in the opposite direction of the man bothering her. This posture reminded me of the "frigidity" the Count speaks of, as it looks stiff and 


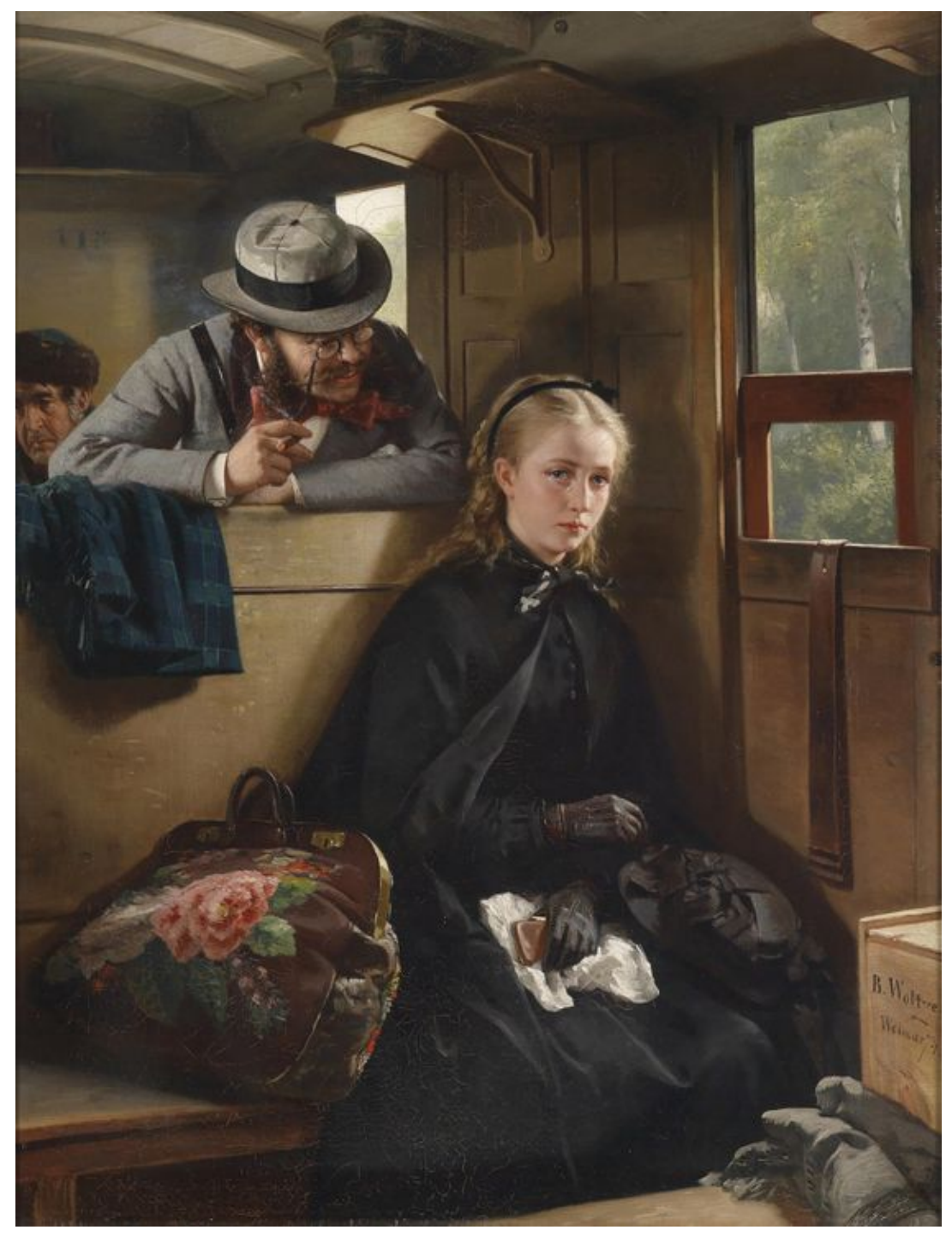

Figure 4: The Irritating Gentleman by Bertholde Woltze, a painting I used for image work during Period Movement. 
unwelcoming. The young woman's gaze toward the painting's viewer relates to Gertrude's breaking of the fourth wall to confide in the audience in Act IV of [Re]Fashion. The woman in the painting appears to be inviting the viewer to help her, due to her direct eye contact and tense shoulders. This is similar to what Gertrude does when she asks the audience to keep watch outside of Millinette's room (Calvano et al 42).

River work in relation to this painting aided my quest to discover Gertrude's resistive deportment when Count Jolimaitre was in the room. Due to the class difference between Gertrude and the Count, I wanted to explore how she would show distaste while staying polite. I was wearing a corset during these in-class exercises, so I focused on the "leaning" element of the painting. "To lean" became the verb I used often in class. Dr. Calvano would often ask us to consider a verb when performing the text we had picked for classwork. In class, I would perform Gertrude's monologue from the opening of Act II scene ii leaning in different directions and emphasizing when I wanted to lean toward or away from my invisible scene partner. Leaning made its way into my work in the scene quoted above. When Count Jolimaitre approached Gertrude, I would lean back or to the side to show that she did not want him in her space. In my class journal, I reflected on the discoveries I made in the exercise:

During the river when I worked with this painting, I felt a lot of energy gathering in my chest and stomach that I could not dismiss because I couldn't move fast enough or big enough to expel it. I played with shoulder plastiques and thought about someone watching me. There was a very subtle movement to acknowledge that I felt someone there, but I was not going to engage them (3). 
This feeling of trapped energy helped me connect with Gertrude physically. She would have felt a lot of energy that she could not release while working in the Tiffany home. As stated in Chapter Two, a way to expel this energy was the use of my hands and fan. From looking at The Irritating Gentleman, I discovered that focusing my gaze on a specific spot on the floor while leaning toward it helped me express Gertrude's frustration without being loud or over the top. As a female servant, there was an expectation put on Gertrude that she should be quiet. Allowing her frustration to build in hand movements showed that rebellion against this expectation was there.

Another painting that helped me investigate Gertrude's physical language regarding the place of women in the period was The Reluctant Bride (1866) by French painter Auguste Toulmouche. This painting, which has been a favorite of mine for years, shows a young woman on her wedding day sitting in a chair surrounded by female family members. She stares straight ahead with the look of complete and utter annoyance on her face. Her chin is down and her eyes flick up toward the viewer, her eyebrows furrowed and mouth turned into a frown. It reminded me of the look I made when first reading Adam Trueman's lines, especially when he spoke about Gertrude. In Act II, Trueman tells Mr. Tiffany that Gertrude "was bred in the country" (23), and this line always made me feel like Gertrude was a piece of livestock being sold to slaughter. The woman in The Reluctant Bride is probably going into an arranged marriage and is being treated like a piece of property. Her family members clutch both of her hands and kiss her forehead in an attempt to comfort her. Her facial expression shines through in this moment, allowing her to convey her true feelings. Her face is in the center of the painting and two of the other women in the piece revolve around it. I decided that I needed to discover moments 


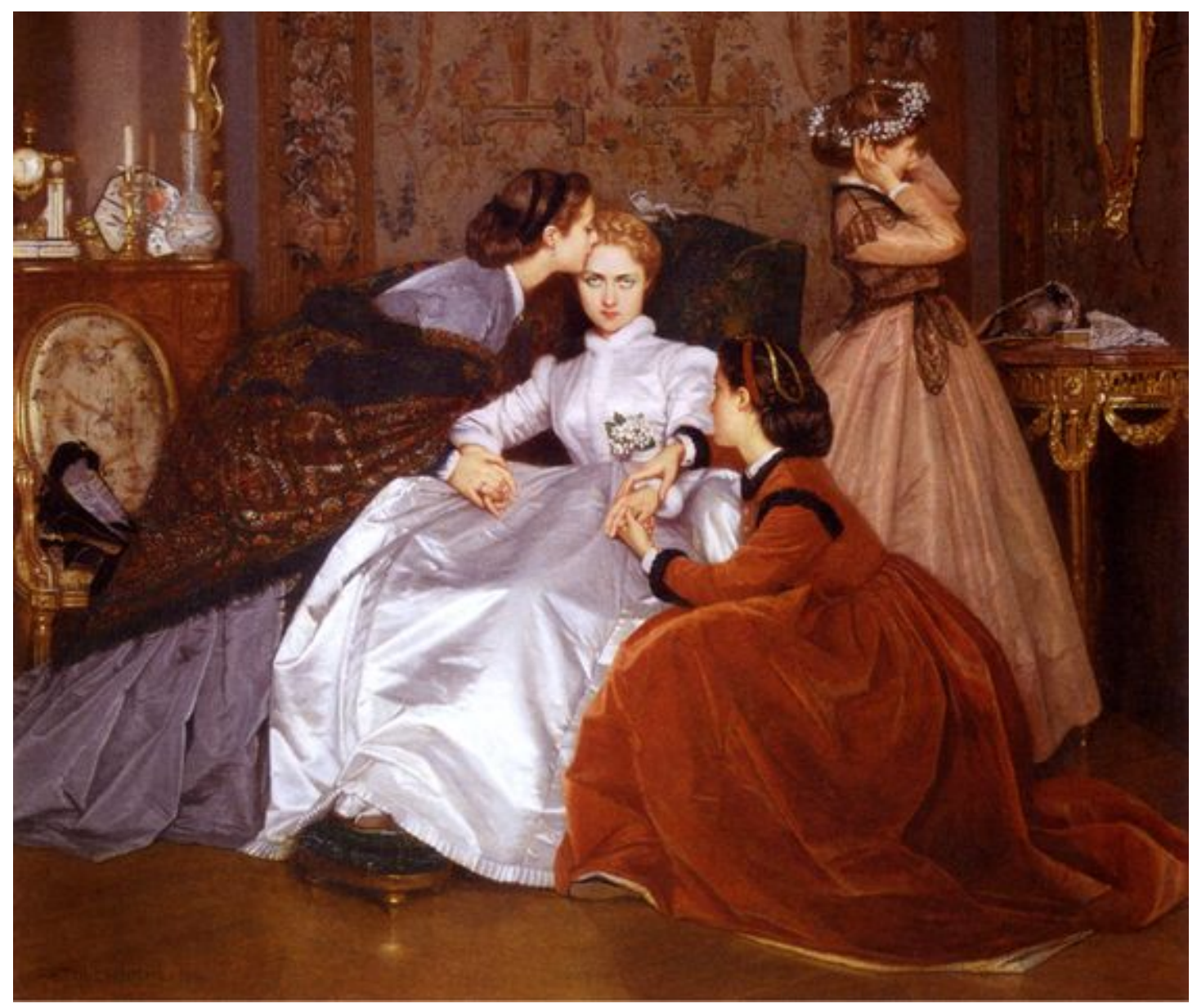

Figure 6: The Reluctant Bride by Auguste Toulmouche, the second painting I used in Period Movement to explore Gertrude's body language. 
like this for Gertrude as well.

Inspired by The Reluctant Bride, I chose to use less contained facial expressions in the last half of the play and make Gertrude's feminist side more obvious. The scene where I felt the most free to use my facial expressions was Act V Scene i. Frustrated, heartbroken, and exhausted, the now fired Gertrude writes a letter to the women who raised her to warn them of her return to Geneva. After Adam Trueman intrudes and critiques her, Gertrude defends her actions and shows him the letter. I labeled this scene in my script the "fuck it" scene, as I felt Gertrude was done with social mores at this point. When Adam Trueman entered, I would look up and gaze at the screen with the same frowning facial expression as the woman in The Reluctant Bride. It felt freeing at this moment to let Gertrude's face express what she was feeling. It also offered another moment for Gertrude to connect with the audience and encourage them to question Adam Trueman. My direct look to the camera asked those viewing, "Are you seeing this?" while providing Gertrude with a companion in that moment. Gertrude was the only female character in the Tiffany house to talk directly to the audience. Like the primary subject in The Reluctant Bride, Gertrude was able to question what was happening as the other women in the house stayed oblivious to the viewer. In scenes before Act IV scene ii, Gertrude would stay focused and control her expressions. This restraint took a lot of work because I am used to using my face to express all of my emotions. I grew up watching Lucille Ball and Carol Burnett and enjoyed mimicking their over-the-top facial expressions. After working with this painting, I figured out that I could have moments in which Gertrude's resistance was more freely expressed; they just needed to be crafted. I wrote in my journal, “Act V is difficult. I can't go too overboard. I really want to dig into 
Adam Trueman here, but perhaps I can do it with my face and not everything. My voice and body can stay calmer, but the occasional eye roll might be nice" (6). Allowing myself to release one element here made Gertrude feel strong and collected in the scene.

\section{A World of Pure Imagination}

Working on Zoom meant that I could not see the set design and background images that were streamed to the audience. During the performance, I could only see myself, my castmates, and green screens. I knew this would be the case for most of the process, so I spent time in rehearsal creating my version of Gertrude's life and the Tiffany house. The use of imagination exercises developed by Stella Adler made Gertrude feel more grounded and solid in her beliefs. To present a confident, cultural feminist Gertrude, I had to be self-assured in what was happening around me and on the screen during the performance.

As an actor, I have been drawn to Stella Adler's technique and her use of imagination over "memory recall," which has been used by method teachers to recreate trauma on stage. Adler said of memory recall, "Drawing on the emotions I experienced

— for example, when my mother died — to create a role is sick and schizophrenic. If that is acting, I don't want to do it" (Flint). Adler believed in research and the building up of multiple resources to create a character. This differs from the standard version of what is called the method, an Americanized form of Konstantin Stanislavski's system of acting. Method acting often emphasizes "memory recall” to find a character's headspace. This version of Stanislavski's system was taught to Stella Alder by Lee Strasberg, who was considered the "Father of method acting in America" (Webb). I have found this technique unhelpful and dangerous, as it can require actors to relive past trauma. With Adler's 
approach, actors can create circumstances to make the world of the play believable without drawing on their lived experience. As she presented her system, Adler challenged the patriarchy to bring her own method technique to the forefront of a male-dominated field. In The Art of Acting, she writes, "You're a storehouse of images. Those images are very powerful. They will turn on your ignition. They will engage your body and mind" (66). She taught that if an actor believed their world, the audience would too. In my undergraduate years at Roosevelt University, I was told that everything needed to be real and that memory recall was the only way to do that. While that may work for some actors, all it does is make me cry or have a panic attack. I cannot act through a panic attack. However, I have enjoyed creating worlds and scenarios in my head, so Stella Adler's technique has proven much more relatable and kept me safe from panic attacks on stage. Her approach is less emotionally draining and disproves the thought that actors must exhaust themselves to live truthfully on stage.

During my rehearsal process for [Re]Fashion, I used one of Adler's imagination exercises to allow me to see Gertrude's world in my Zoom box and thereby present a resilient young woman that is comfortable and confident in her world. Adler's exercise starts off by describing something in the room. I had a chair with me on stage, so I would describe the chair in detail and then consider what I had missed. I would describe the chair again with as much detail as possible. Adler believed that to create our world on stage, we first had to be able to describe everything that is real around us. She states, "The actor knows how easy it is to lie, to fake. What he must do is surround himself with things that are true. As long as he can focus on those, he won't be tempted to lie" (74). It is difficult on Zoom to "surround" oneself with "things that are true." I was standing in a 
room all alone, and my connection with everyone and everything felt very forced in the beginning. To continue with Adler's description exercise, I started to journal about Gertrude's life as a child, describing her day-to-day schedule. After that, I moved on to describing the Tiffany home in detail based on historical images I had seen during my research. I found photos and recreations of servant's quarters from the mid-nineteenthcentury and from them created Gertrude's room in my journal. This imagined bedchamber included the books and magazines she may have snuck down to her room as well as sheet music that papered the walls. I considered her reading of Godey's Lady's Book, an American magazine from the mid-nineteenth-century that published poems and short stories written by women. Gertrude's reading of this magazine would have helped her keep up with current trends to teach Seraphina as well as help her discover what other educated women were writing about. Her reading of works authored by women related to her desire for independence. By reading these compositions, Gertrude would be rebelling against the standard of authors usually taught to young women at the time. Sneaking this magazine down to her room was a piece of knowledge I had that helped emphasize her rebellious streak in my acting.

These descriptions helped keep Gertrude's cultural feminism legible, even when I felt that all of my work was slipping away from me during tech week. It was a long four day process of standing and staring at our screens while the technical crew adjusted the images that the audience on Youtube would see. While my castmates would often play on their phones or do homework during this time, I spent much of it reciting my descriptions to myself and turning my studio room into the Tiffany house in my head. I set up markers in my eye line to represent different plants of the conservatory. I created these plants in 
my mind every night and would catalogue them during the scene with Colonel Howard. My objective for most of Act II Scene ii was to make sure I checked on all of my favorite plants. As the Colonel walked in to interrupt Gertrude's gardening work, she gets a bit flustered because she can no longer focus on her plant children. When the Count suggests she pick roses for him, she is insulted because she could never ruin her roses for a man she doesn't know. Gertrude and I were both comfortable in the conservatory, so her refusal to do what the Count asks felt supported by her security. The conservatory was her space. She was not going to allow a man to enter it, boss her around, then insult her. I could show resistance in this scene because of Gertrude's security in the conservatory. By having these plants in my head and markers to identify where they would live in the space, I was able to find consistency and believe that I was really there. The conservatory became a safe space for me; a place where Gertrude could focus on her work and be herself. Hopefully, my belief of the space allowed the audience to believe it as well.

\section{Musical Me}

As an actor and a woman living in American society, I have always had a voice that people felt the need to comment on. When I went to Roosevelt University in Chicago, everyone suddenly started to tell me I had such a funny southern accent. I lived in Nashville my whole life until that point, so I did not know I had an accent. I would drawl the word "theatre" out to three long syllables, "thee-ay-tur" and my entire BFA class would laugh. At that point, I became determined to speak without my accent. When that was gone, professors started to point out that my voice was too nasal and whiny. At auditions, directors would listen to me speak and say, "Now can you do something in your real voice?" I would nod and fake a deeper, rounder sound to sound more pleasant. 
As a professional actor, my voice has been described as a banshee, shrieky, and annoying. I am a natural soprano and tend to flip into my upper register when excited and male directors have told me this was unpleasant to hear. I've spent a lot of my 32 years on this planet trying to change myself to be what other people want, but when I started to work on Gertrude, I made the decision that I would not change my voice. I like my voice and I wanted to embrace it in this role. Like Gertrude, I was happy to acknowledge the parts of my voice that society has defined as feminine by speaking with a higher pitched, lilting sound. Incorporating this sound was consistent with the cultural feminist championing of what was then considered as innately feminine virtues.

Including musicality in Gertrude's voice helped validate her work as a musician, which was inspired by her cultural feminist "love of independence" (Mowatt, Fashion 26). I am a classically trained singer and music has always been a huge part of my life. Gertrude is the music teacher in the house, but we never see her interact with an instrument or talk about music. I decided the best way to show this element of her personality was to have musicality in her voice. To establish this, I looked at the Estill Voice Model, which I learned in Professor Rachel Carter's Graduate Voice class during my first year in the MFA program. This vocal technique includes learning about the voice's anatomy and building vocal recipes using the anatomy to create a sustainable sound. Jo Estill created this technique to help singers and actors safely manipulate their voices while embracing one's natural voice and placement. At Roosevelt University, I was taught versions of Linklater and singing techniques that forced the voice to be the “ideal" actor voice instead of celebrating a person's unique traits. Professors were often encouraging me to yawn and speak in the lower part of my register even though it was 
uncomfortable for me. I decided to use Estill's method and build a vocal recipe for Gertrude to keep my voice consistent throughout the performance. My vocal recipe for Gertrude started as follows: high velum, mid larynx, retracted false vocal folds, narrow aryepiglottic sphincter (AES), and thick vocal folds that occasionally flipped to thin. Each of these positions provides a different value to the sound. The vocal folds affect the voice's quality and breathiness, the velum affects resonance, the larynx affects tone, and the AES affects brightness and projection (Steinhauer 162-221). In layman's terms, this recipe results in a bright, projected, and supported voice. It feels and sounds forward; some may even say nasal. It is a vocal recipe I am comfortable with and was easy to sustain during the show's run without feeling vocal fatigue. Moreover, this recipe resulted in a voice for Gertrude that would cut through a room and allow her to be understood. It made her voice distinct and strong, which helped identify her as an independent woman that wanted her voice to be heard and acknowledged.

Adding register work to Gertrude's voice made the cultural feminist aspect of her character design more intelligible for me. The singing voice has areas known as registers and for women, those are identified as the head voice and the chest voice. By flipping back and forth between these registers, the up and down made Gertrude's voice singsongy. When journaling, I would describe it as a yodel. For my vocal recipe, this meant thinning out the vocal folds, widening my AES, and raising the larynx slightly when I wanted to go into my head voice. This sound felt feminine to me as it includes pitch that is often associated with female voices. I embraced this register change and pitch in Act III scene ii when Gertrude confronts Millinette and Count Jolimaitre in Millinette's chamber. The Count informs Gertrude that he is going to tell Mrs. Tiffany of her 
insolence and Gertrude states, "His own weapons alone can foil this villain. Count! Perhaps the least said of this matter the better!" (Calvano et al 38). In this line, I started in my chest voice, speaking to the audience. To get the Count's attention, I would flip into my head voice and call, "Count!" and continue the scene high in my register, giggling and floating my words. This technique was used to convince the Count that Gertrude was now a complying woman, flirting with her voice. Gertrude acknowledges that she has to convince Count Jolimaitre that she is a mere woman, susceptible to his power in the home. By including qualities in her voice assigned to women in her call to the Count, Gertrude uses patriarchal notions of gender to manipulate the situation. Related to cultural feminism, she uses qualities prescribed as feminine to keep herself safe.

While rehearsing, I realized that the register change was not providing as much musicality as I wanted, so I looked to other vocal elements to show Gertrude's relationship to her job. I decided to embrace it fully and sing certain lines. I did not want them to seem out of place or random, so I played around with emotions that might cause singing. I had marked a few areas in the script where it could be beneficial, but it happened by accident one night when I worked on Act II Scene ii. Count Jolimaitre had just informed Gertrude that he would like to have an affair with her, and I became unsettled and sang Gertrude's response, "But I am an American. Your conduct proves that you are not one!" (Calvano et al 22). Dr. Calvano stopped me and asked what I had just done. I replied that Gertrude was feeling quite nervous, so she sang to calm herself. Dr. Calvano nodded, "Do more of that." That night in my journal I simply wrote, "Yay!" (5). Embracing my instinct and natural voice worked to bring Gertrude's voice off the page. In the past, I may have stifled the thought to sing because it was placed in a higher 
pitch than my speaking voice. However, it lent to the cultural feminist ideal of femininity that I was adopting with Gertrude and strengthened my character voice overall.

These three elements of my acting process enabled me to find confidence in working alone which led me to enfold Gertrude's independent nature in my performance. While my director, production crew, and fellow actors were on the screen and provided much guidance, I did feel that the manner of working on Zoom required a lot of selfdiscovery and private rehearsal. By planning what I wanted to work on during the process, I had time to seek out and find exercises and methods that worked for me in a lonely pandemic world. The discovery of cultural feminism and the inclusion of it in my acting process helped me modernize Gertrude while keeping her true to the script. 
CONCLUSION:

\section{[RE]FASHION IS THE LATEST FASHION \\ "That's all." -Miranda Priestley, The Devil Wears Prada}

My path to the completion of my thesis was not as linear as I hoped it would be. I spent hours staring at Mowatt's original text, the adaptation, and my computer screen wondering, "What am I doing?" I flip-flopped often, loving the play and process one minute and hating it the next. On occasion, I still question if my focus on Gertrude's feminism and strength helped or hindered my performance. What would have happened if I had let it go and focused on her love for Colonel Howard or her desire for a family instead? I do know the answer, of course. I would not have related to her as easily and I would have felt that I was being more performative instead of living in the character. But my brain likes to hang out with "what ifs."

In the beginning of my thesis process, I set out while writing to offer methods for adapting to unknowns when working digitally. This morphed when I discovered new waves of feminism that I did not know existed. Finding cultural feminism helped me rethink how I critique femininity and strength. It has also provided a new way for actors to read period pieces. Considering what was measured as rebellion in a period while reading or rehearsing a play can aid an actor in discovering a character's inner life and struggle. While I started my journey judging the women in the play, I ended the process relating to each of them and understanding their motives. Exploring cultural feminism gave me insight into the holding up of feminine virtues that happens in Fashion and 
broadened my knowledge of the history of feminism. It took Anna Cora Mowatt from a villain to a hero in my mind.

Two elements that can help an actor struggling with antiquated gender politics in a play are historical research and image work. I needed to know the history of the time to discover how Gertrude fit into her moment. Understanding the world of the play and the period in which it was written grounded my acting. After conducting my research, I stopped doubting my choices and trusted that the work would be there. I felt closer to Gertrude and understood the choices she made in the course of the play. While I originally detested how she stayed silent during moments of confrontation with Mrs. Tiffany and Count Jolimaitre, my research into the period's prescriptions on women of her occupation proved that she had no other choice. Knowing that, I was able to focus that energy on other areas of my body and make her a more realized character. I showed Gertrude's resistance by expelling energy through my hands and "speaking" with my fan. For the first time in my life, while performing, I did not feel uncomfortable in my body. I was confident in Gertrude's movement because I had done the research.

The image work and Adler imagination exercises were crucial to viscerally bringing the historical research to life, and they could assist other actors similarly working on bringing a character in a period play's resistance to the forefront. As I looked at paintings from the nineteenth-century, I started to imagine them as real-life situations and it let me live in Gertrude's world in my head. The Irritating Gentleman by Bertholde Woltze and The Reluctant Bride by Auguste Toulmouche provided images that brought the Tiffany House to life. Stella Adler affirms, "The imagination is what animates our instrument, keeps it in tune. It's the ignition key. Without it, nothing else works" (64). 
Examining images was my "ignition key" to understanding the play and Gertrude's rebellion. Without it, my performance would not have worked. It allowed me to feel more comfortable on Zoom and in the studio room where I was working. Instead of being distracted by my green screen, the lack of set, or the tiny versions of my castmates on my screen, I felt immersed in the Tiffany house I had created. When I felt the technical process was too stressful, I was able to refocus and remind myself that as long as I believed the world I had created, the audience would too. Zoom theater is not a super rewarding experience. It can cause a lot of overthinking and sometimes it feels pointless. Connecting back to my favorite paintings and the imagination exercises I did provided a solid way for me to get out of my head and stop worrying about my screen. I expect that within a year or two, online theatre will be a distant memory. However, the image work and use of imagination can still be helpful. Even when working on a stage set, actors should imaginatively build their world and not only rely on designers to do it for them. Image work provides a way to explore breaking social rules their character must conform to. It helped me relate to Gertrude's restrictions and discern the subtle way she shows rebellion. While I originally thought she was a goody-two-shoes, historical research and image work helped me acknowledge the weight of rules she was carrying and that she was resisting in her own way.

A way to relate to a character type that one does not normally play is to combine empathy and research to connect with that character. Ingénues do not have to be scary or boring. I discovered this as I delved into Gertrude's inner life and the energy and power she possessed that she had to keep secret. My Grotowski river work and imagination exercises really helped me see how much goes on in a character's head that the audience 
doesn't know. I now trust that anyone can play any type, and I hope my journey into the land of ingénues gives other actors methods to reach outside of their comfort zone.

Discovering Gertrude's cultural feminism enabled me to consider the way modern theatre presents gender and challenge it. I was proud to present a character I considered more than an ingénue. I found so much of myself in Gertrude during the rehearsal process and playing her eventually felt like coming home. This play was not my ideal thesis performance project or one I ever imagined myself performing. My experience this year has helped me figure out ways of letting go and helped me look at characters in a deeper way. I learned not to write a character off upon the first reading of a script as there is always more to discover. Even if lines cannot be rewritten, focusing on intention, how a character relates to you, and the rules of the world in which the character exists can help the actor and audience relate to any play. Modernizing stories from the past allows them to continue to be told and studied. Presenting a more legibly resistive Gertrude to a modern audience allowed me to consider how theatres and "type" casting reaffirm gender prescriptions. Traditional casting prevents society from moving forward in regards to representation and beauty standards. As theatres continue to tell older stories, they should consider what they want their audience to walk away with. Retelling period pieces with a modern lens allows audience members to reflect on how society has changed and what we need to continue to work on to move forward. To quote Professor Reddi Turner, "review the past and revision the present into an informed future" (Calvano et al 62). 


\section{REFERENCES}

Adler, Stella, et al. The Art of Acting. Applause, 2000.

Barnes, Eric Wollencott. The Lady of Fashion: The Life and the Theatre of Anna

Cora Mowatt. Scribner, 1954.

Burke, Sally. American Feminist Playwrights: A Critical History. Twayne, 1996.

Calvano, J. Ariadne, et al. [Re]Fashion. U of Louisville, 2021.

Chinoy, Helen Krich. "Art Versus Business: The Role of Women in American

Theatre." A Sourcebook on Feminist Theatre and Performance: On and

Beyond the Stage, Psychology P, 1996, pp. 23-30.

Dolan, Jill. The Feminist Spectator As Critic. U of Michigan P, 1991.

Donovan, Josephine. Feminist Theory: The Intellectual Traditions of American Feminism. New expanded ed., Continuum, 1992.

Dudden, Faye E. Women in the American Theatre: Actresses and Audiences, 1790-1870. Yale UP, 1994.

Duvelleroy, Jean-Pierre. Fan Flirtation, 1850.

Flint, Peter B. "Stella Adler, 91, an Actress And Teacher of the Method." The New York Times, The New York Times, 22 Dec. 1992, www.nytimes.com/1992/12/22/obituaries/stella-adler-91-an-actress-and-teacher-ofthe-method.html. Accessed 15 Mar. 2021.

Goldentul, Zhanna. Fashion Costume Research. U of Louisville, 2020.

Haggard, Jordan Tudor. Thesis Journal. U of Louisville, 2021. 
, ___ _ Period Movement Journal. U of Louisville, 2020.

Hughes, Kathryn. The Figure of the Governess. 13 Feb. 2014, www.bl.uk/romantics-and-victorians/articles/the-figure-of-the-governess. Accessed 23 June 2020.

Martine, Arthur. The Polite Ladies' Guide to Proper Etiquette. Skyhorse, 2015.

Mitchell, Margaret, et al. Gone with the Wind. Macmillan Company, 1936.

Monet, Claude. Women in the Garden. 1866, Musée D’Orsay, France.

Mowatt, Anna Cora. Autobiography of an Actress: or, Eight Years on the Stage. Forgotten Books, 2016

____ Fashion; Or, Life in New York. Creative Media Partners, 2016.

National Assessment of Educational Progress. U.S. Dept. of Education, 2013. nces.ed.gov/nationsreportcard/data. Accessed 08 Jan. 2021.

Oneill, Therese. Unmentionable: The Victorian Lady's Guide to Sex, Marriage, and Manners. Back Bay Books/Little, Brown and Company, 2018

Rogers, Richard, and Oscar Hammerstein II. The King and I. Concord Theatricals, 1951.

Shapiro, Marilyn. "Anna Cora Mowatt: Forgotten Dramatist and Actress." Women's Contribution to Nineteenth-Century American Theatre. Publicacions de la Universitat de València, 2011, pp. 85-94.

Stansell, Christine. City of Women: Sex and Class in New York, 1789-1860. Knopf, 1986.

Steinhauer, Kimberly, et al. The Estill Voice Model: Theory \& Translation. Estill Voice International, 2017. 
Toulmouche, Auguste. The Reluctant Bride. 1866, France.

Tudor, Christine. Personal Review of [Re]Fashion. 2021.

Webb, Jim. "5 Basic Facts About Lee Strasberg." Acting Magazine, 1 Dec. 2020, actingmagazine.com/2019/09/04/5-basic-facts-about-lee-strasberg/. Accessed 5 Mar. 2021.

Wharton, Edith, and Anna Catherine Bahlmann. My Dear Governess: The Letters of Edith Wharton to Anna Bahlmann. Edited by Irene Goldman-Price, Yale UP, 2012.

Woltze, Bertholde. The Irritating Gentleman. 1874, Germany. 


\section{CURRICULUM VITAE}

NAME: $\quad$ Jordan Tudor Haggard

ADDRESS: 1021 Tyne Blvd.

Nashville, TN 37220

DOB: $\quad$ February 09, 1988

EDUCATION

MFA in Performance

University of Louisville, Louisville, $K Y$

May 2021

Thesis Title: [Re]Fashioning a Means: Exploring and Adapting Anna Cora Mowatt's Fashion with a Feminist Lens.

Thesis Committee: Dr. Janna Segal, Professor Rachel Carter, Professor Frank Kelderman

BFA in Musical Theatre

Roosevelt University, Chicago, Illinois

May 2010

\section{ACADEMIC TEACHING EXPERIENCE}

Department of Theatre Arts, University of Louisville

Adjunct Faculty

August 2019-December 2020

- Instructor of record for two sections of Theatre Arts 224 (Acting for Non-Majors) over two semesters

- Planned and taught undergraduates in a beginning course based upon contemporary realistic styles of acting

- Utilized theater games, improvisation, vocal and physical exercises, open scenes, and monologues

- Completed Acting Pedagogy course prior to instruction

Graduate Teaching Assistant

August 2018-December 2018

- Served as a Graduate Teaching Assistant for Professor Geoffrey Nelson for Theatre Arts 207 (Enjoyment of Theater)

- Taught two separate sections of undergraduates for Friday classes for one semester 
- Utilized Power Point and other electronic media to enhance pedagogical technique

- Recorded grades and assisted in the creation of quizzes and exams

Graduate Teaching Assistant

January 2019-May 2019

- Served as a Graduate Teaching Assistant for Professor Sidney Monroe Williams for Theatre Arts 224 (Acting for Non-Majors).

- Taught one section of undergraduates for one semester

- Taught Boal based theatre games, improvisation, mime, and coached monologues

- Led discussion of play critiques

- Recorded grades on Blackboard and assisted in the creation of exams

\section{WORKSHOPS AND COACHING}

Department of Theatre Arts, University of Louisville

The Masks We Wear, Director

February 2021

- Taught a writing and monologue workshop for victims of domestic violence in partnership with the PEACC Center

- Used improvisation games, meditation, and vocal and physical exercises

- Implemented intimacy pillars for performance to keep actors safe

Private Monologue Coaching

February 2018-Present

- Coached audition cuts to help actors prepare for SETC and UPTA auditions.

\section{ACTING EXPERIENCE}

National and Regional Tours

A CHRISTMAS CAROL

A CHRISTMAS CAROL

THE TAMING OF THE SHREW

Nell/Mrs Dilber

Mrs. Fezziwig

Trainia

\section{Regional Theatre}

AS YOU LIKE IT

THE MUSIC MAN

THE TAMING OF THE SHERW

TWELFTH NIGHT

9 TO 5

FIDDLER ON THE ROOF

ALL SHOOK UP

THE GREAT GATSBY

BLOODY ...ANDREW JACKSON

THE ROCKY HORROR SHOW

XANADU

RENT

INTO THE WOODS

YOU CAN'T TAKE...YOU
Phebe/Amiens

Ethel Toffelmier

Nathaniel

Maria

Judy Bernly

Yente

Matilda

Catherine

Female Soloist

Columbia

Calliope

Maureen

Florinda

Essie
Nebraska Theatre Caravan

Nebraska Theatre Caravan

Arkansas Shakespeare

Shake on the Lake

Arkansas Shakespeare

Shakespeare in the Vines

Gaslight Dinner Theatre

Round Barn Theatre

Sonoma Valley Shakes

Street Theatre Company

Boiler Room Theatre

Nashville Dinner Theatre

Sturges Center of Perf. Arts

Towne Centre Theatre 
University Theatre

[RE]FASHION

ALMOST, MAINE

THE TAMING OF THE SHREW

A PIECCE OF MY HEART

Gertrude

University of Louisville

SIX DEGREES OF SEPARATION

Rhonda/Ginette

Guilia

Mary Jo

Ouisa

\section{RELATED THEATRE EXPERIENCE}

Department of Theatre Arts, University of Louisville

Love Among the Ruins, Reader

March 2021 - April 2021

-Acted as a reader for a staged reading in the Spring of 2021

Hashtag, Vocal Coach

February 2021 - April 2021

- Instructed actors on safe vocal technique in a large space

- Helped with dialects and mimicking of celebrity voices

Fires in the Mirror, Assistant Director

August 2019 - November 2019

- Focused on directing undergraduate cast members in their monologue work

-Aided Director Ariadne Calvano with blocking and choreography

Theatre Box Office Assistant

August 2018 - May 2020

- Coordinated multiple jobs simultaneously

- Helped write and create programs for university productions

Sonoma Valley Shakespeare, Sonoma, California

Production Makeup Designer

May 2015 - August 2015

- Designed makeup plots for The Great Gatsby

- Taught actors how to apply plots and do touchups outside

\section{SERVICE}

Department of Theatre Arts, University of Louisville

Undergraduate Curriculum Committee

January 2021 - May 2021

- Helped recruit for the University of Louisville theatre department

- Created a brochure for prospective undergraduate theatre majors

PROFESSIONAL TRAINING

Intimacy Directors and Coordinators (IDC) Level One Intimacy Direction

2021

Instructors Claire Warden and Samantha Kaufman

Intimacy Direction and Academia

IDC workshop 
Acting Intimacy Essentials

IDC workshop

Consent in Rehearsals

2021

IDC workshop

Meisner in Music with Jillian Paige

2020

Acting the Song with Tituss Burgess

2012

\section{NOMINATIONS}

The Kennedy Center American College Theatre Festival:

- 2020 Irene Ryan Nominee Region IV 